\title{
XIII. The polymerization of the metallic oxides
}

\section{Louis Henry}

To cite this article: Louis Henry (1885) XIII. The polymerization of the metallic oxides, Philosophical Magazine Series 5, 20:123, 81-117, DOI: 10.1080/14786448508627732

To link to this article: http://dx.doi.org/10.1080/14786448508627732

曲 Published online: 29 Apr 2009.

Submit your article to this journal $2 \pi$

Џ Article views: 2

Q View related articles $\asymp$ 
THE

LONDON, EDINBURGH, AND DUBLIN

\title{
PHILOSOPHICAL MAGAZINE
}

\author{
AND \\ JOURNAL OF SCIENCE. \\ [FIFTH SERIES.] \\ $A U G U S T 1885$.
}

XIII. The Polymerization of the Metallic Oxides. By Lours Hennr, Professor of Chemistry in the Catholic $C^{r}$ niversity of Louvain*.

\section{Introduction.}

$\mathrm{ONE}^{\mathrm{NE}}$ of the principal objects of Physical Science, in fact its principal object, is to determine the natural relation of things. It is by comparisons logically established between the things themselves that these relationships are disclosed. An essential condition to be observed in researches of this kind is to compare only those objects which are really comparable. Stated in the terms of chemical science, this general condition of all work undertaken with a truly scientific object consists in establishing a comparison only between the chemical molecules themselves. Molecules are, in fact, for the chemist the veritable chemical individuals - they are the bodies themselves in their simplest, and at the same time their most complete, expression. Molecules find a graphic representation simple and concise, and sometimes even sufficiently perfect, and in every case susceptible of a great degree of precision, in the chemical formula at present in use.

Formulæ, however, only maintain their full and complete utility so long as they are the exact and complete representation of the molecules of bodies, - of bodies between which chemical actions occur, of bodies which we possess in reality, and which are the veritable objects of our comparisons. This representation becomes exact and complete only when the for-

* Communicated by Prof. Carnelley.

Phil. Mag. S. 5. Vol. 20. No. 123. August 1885. 
mula indicates the three facts fundamental to the being of the molecule, viz. (1) the nature of its constituent elements, (2) the actual number of atoms of each present, and (3) their combining proportion.

We are still far from this degree of completeness. Our knowledge of bodies from the molecular point of view is very incomplete, and especially so as regards Mineral Chemistry. Not only is the number of compounds, of which the constitution and structure have been successfully determined, very limited, but there are a great number, I might even say the greater number, to which we are still unable to attribute a formula expressing in a satisfactory manner the true size and real weight of the molecule. The formulæ used in Mineral Chemistry are in the majority of cases only the empirical formulæ, indicating merely the nature and relative weights of the atoms of the elements in the compound, and are wholly silent as to the absolute quantity of matter, or the actual number of atoms present in the molecule. They do not give therefore any idea either of its size, or of its absolute weight, or of its internal structure. The properties of compounds do not depend on chance ; they depend chiefly no doubt on the nature of the elements constituting the molecule, but they are also conditioned by the internal structure of the latter, and by its size and weight.

It is to Berzelius that we owe the idea of isomerism, withont which a rational study of the innumerable compounds of carbon would be absolutely unattainable. However it may be, each of these three great factors in the diversity of compound bodies exercises a special and preponderating influence on certain classes of properties. If, on the one hand, the chemical activity of a given compound depends especially on the essential nature of the atoms constituting the molecule, and on the constitution of the latter, on the other, an increase in its weight powerfully affects the physical and mechanical properties.

Whatever may be the specialization of this dependence, the properties of a body, considered individually or relatively, the one in relation to the other, their analogies and their differences, can only be well understood when we know the size of the molecule.

Just as the adoption of rational and true formulæ for the various compounds may render great service in a systematic study, so in the same degree will the adoption of imperfect formulæ, artificial and false, or even incomplete and expressing only simple relations, lead to results which are untrue. Such formulæ mislead by obscuring, or even by totally concealing, 
the real relations of bodies. They create imaginary relationships, removing apart those bodies which ought to be brought together, and bringing those together which ought to be kept apart. Our formulæ should be like glasses of a perfect transparency, through which the bodies should be seen as they are, and not like screens to hide, or disguises to disfigure.

Most formulæ now in use refer to the perfect gaseous state. These formulæ are undoubtedly excellent for bodies of which the normal state is gaseous ; but their exclusive use is insufficient, and creates a void to be regretted in the comparative study of bodies, both from the individual and general point of view. The number of bodies naturally gaseous is in fact very limited; and if the number of those capable of becoming so is very considerable, still there are many which are not, and with an absolute or relative fixity resist the highest temperatures, or are decomposed.

Our usual molecular formulæ are therefore necessarily insufficient, being inapplicable to numerous compounds, and to the various states which the same body is capable of assuming. These formulæ, referring to the perfect gaseous state, do not tell us anything of the molecular nature of these same bodies when in the ordinary condition. Thus it is, to appeal to classical examples, with the formulæ of sulphur, and of the fatty acids, or at least with the first terms of the latter series.

It is in all respects desirable that the molecular formulæ of bodies should refer to their natural state, and that the several formulæ should be determined for the various physical states which the bodies can either naturally or artificially assume. That is the only way to avoid misconceptions, artificial difficulties, false analogies between unlike bodies, and to retain for various compounds their own physiognomy.

There is no teacher of Chemistry who has not frequently noticed, both in mineral and in organic chemistry, differences in the properties of bodies, which are often most profound, and totally beyond theoretical prevision, notwithstanding that the bodies are apparently related as regards their formulæe and the analogy of their composition. It is easy to say that there are exceptions and anomalies. But in spite of these words, the difficulties still exist in all their entirety, embarrassing the mind of both teacher and taught. The greatest caution should be used in qualifying exceptional and anomalous facts; otherwise confusion is created in the mind, and place is given to chance in the occurrence of natural facts : it is the ruin of law and general principles. It is well to remember the old adage, applicable in the physical as well as G 2 
in the natural world, that exceptions prove the rule. True exceptions, true anomalies, have no real existence; these apparent deviations in the effects of a general known cause are due to the influence of other causes, acting simultaneously, the existence of which remains momentarily hidden from view.

Among the difficulties which are met with in the comparative study of bodies, there are some which are peculiarly embarrassing, and which it would be chimerical to try to solve under present circumstances. But there are others, and I believe a very considerable number, which are purely artificial, without real foundation; difficulties which would vanish of themselves if we only had a less imperfect knowledge of the bodies with which they occur-if, in fact, the chemical signification of these bodies molecularly in relation to others were only clearly and surely defined.

This point of view, from which bodies should be studied, is not absolutely new. Sulphur and the fatty acids, especially acetic acid, are well-known examples of substances which have been clearly distinguished in their various physical states. Moreover, the determination of the relative molecules of bodies in their various states also touches on a question of still greater interest, viz. that of the chemical relationships of the various physical states in which they occur.

The molecular formulæ at present in use refer to the gaseous state, and the principal method of determining them depends on the vapour-density. This process, simple and expeditious, is undoubtedly excellent in all cases in which it is applicable. Others, however, are necessary for the determination of molecules in a state other than that of a perfect gas. It is in the complete study of bodies in their various conditions that we should find indications sufficient for information as to their molecular nature. The several circumstances which characterize the chemical molecule, both chemically and physically, are in intimate connection, and to determine this molecule we can appeal to all connected therewith, either in its past, present, or fature : in its past, to examine its mode of formation and the various circumstances bearing on its chemical origin; in its present, to carefully investigate the whole of its properties-physical, mechanical, and chemical ; in its future, to study the reactions in which it may take part, the products of its decomposition, its metamorphoses, \&c.

This complete study of bodies, from both the statical and dynamical point of view, always gives, though it may be imperfect, valuable information for solving our present problem. It is, however, necessary to say, that when I speak of actual molecules and of actual molecular formulæ, I do not 
forget that these molecules, as well as the formulæ which express them, are really only relative. We do not know, and we shall never know, that which is truly and absolutely a molecule, for we cannot and never shall be able to obtain one singly and alone. We possess, and we shall always possess, only groups of molecules. The character of reality which we wish to give to our molecules and to our formulæ is essentially, then, a relative one. What we have to determine are real relationships between real bodies. These relationships of analogy and difference remain practically the same if, in the impossibility of verifying them between the bodies themselves, we seek for them between the same bodies in a modified condition ; modified simultaneously, however, and in a similar manner. It results from these considerations that it is of great importance to examine chemical phenomena from the molecular point of view. To establish real molecular formulæ for bodies (i. e. formulæ truly and universally comparable) is therefore an object eminently worthy of attention. It is this idea which has induced me to undertake a lengthened series of theoretical and experimental studies on compounds in both mineral and organic chemistry, and more particularly as regards the metallic oxides.

\section{The Peculiar Character of the Metallic Oxides.}

A comparative examination of the oxides and chlorides leads to a general fact. Chlorides are fusible compounds, and, with few exceptions, volatile. It has been long observed that chlorine gives wings to the metals, as one may say. Volatility is especially noticeable in the chlorides of the fixed elements, and particularly of the metals. The corresponding oxides, on the contrary, are distinguished by their fixity and infusibility, either absolutely or relatively. The following table shows that this difference is general:-

\begin{tabular}{|c|c|c|c|c|}
\hline & $\begin{array}{c}\text { Mole- } \\
\text { cular } \\
\text { weight. }\end{array}$ & $\begin{array}{c}\text { Physical } \\
\text { state. }\end{array}$ & Fusibility. & Volatility. \\
\hline 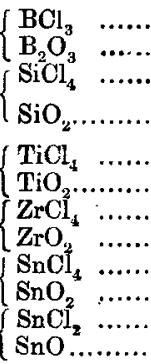 & $\begin{array}{c}117 \\
70 \\
170 \\
60 \\
192 \\
82 \\
231 \cdot 5 \\
121 \cdot 5 \\
260 \\
150 \\
189 \\
134\end{array}$ & $\begin{array}{l}\text { Liquid. } \\
\text { Solid. } \\
\text { Liquid. } \\
\text { Solid. } \\
\text { Liquid. } \\
\text { Solid. } \\
\text { Solid. } \\
\text { Solid. } \\
\text { Liquid. } \\
\text { Solid. } \\
\text { Solid. } \\
\text { Solid. }\end{array}$ & $\begin{array}{c}\text { Fuses 577\%. } \\
\left\{\begin{array}{c}\text { Fusible in oxyhy- } \\
\text { drogen flame. }\end{array}\right\} \\
\ldots \ldots \ldots . . . . \\
\text { Infusible. } \\
\text { Fusible. } \\
\text { Infusible. } \\
\ldots \ldots \ldots . . \\
\text { Infusible. } \\
249.3 . \\
\text { Infusible. }\end{array}$ & $\begin{array}{c}\text { Boils } 17^{\circ} . \\
\text { Fixed. } \\
\text { Boils } 59^{\circ} . \\
\text { Fixed. } \\
\text { Boils } 135^{\circ} . \\
\text { Fixed. } \\
\text { Sublimable. } \\
\text { Fixed. } \\
\text { Boils } 115^{\circ} .4 . \\
\text { Fixed. } \\
617^{\circ}-628^{\circ} . \\
\text { Fixed. }\end{array}$ \\
\hline
\end{tabular}


Table (continued).

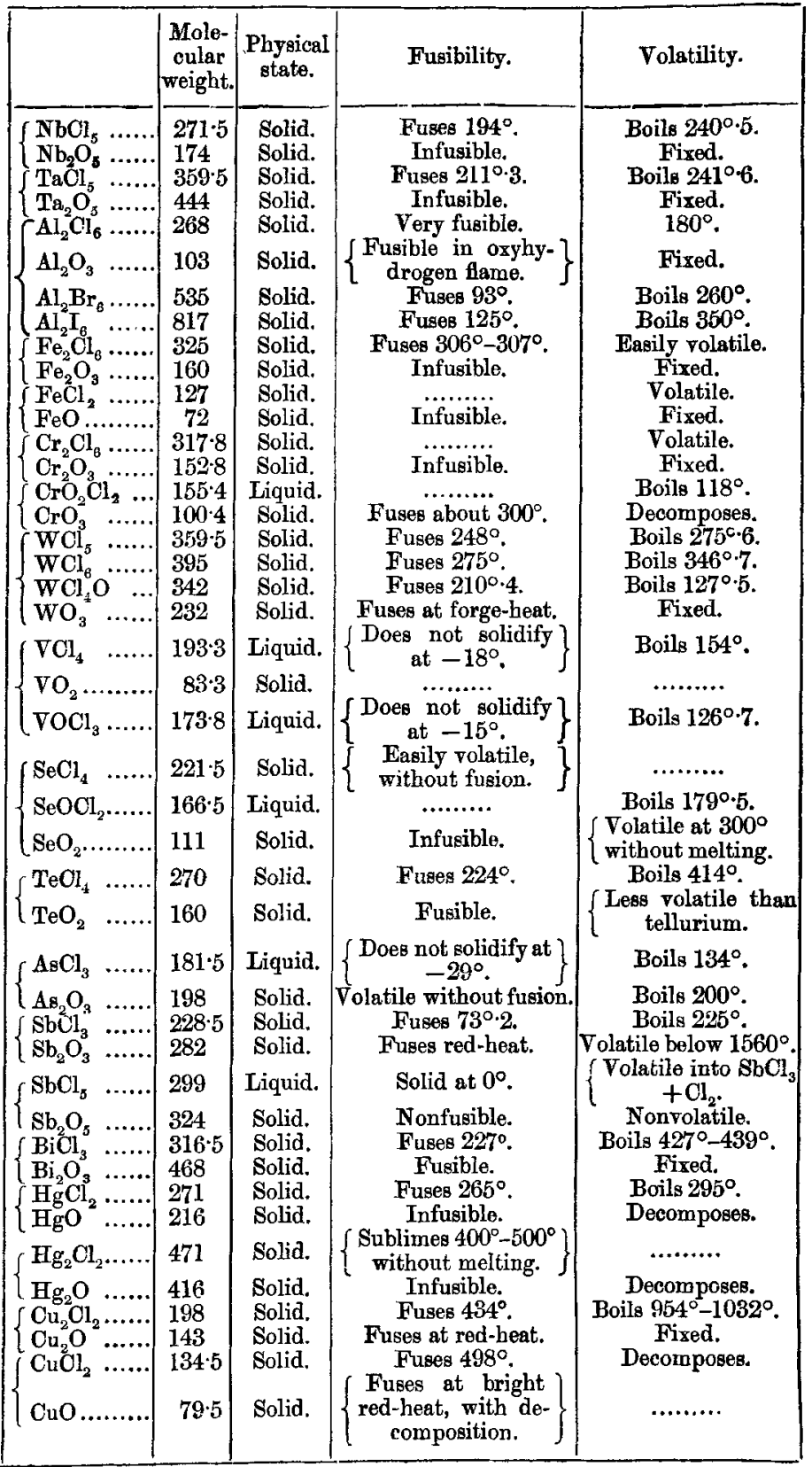


Table (continued).

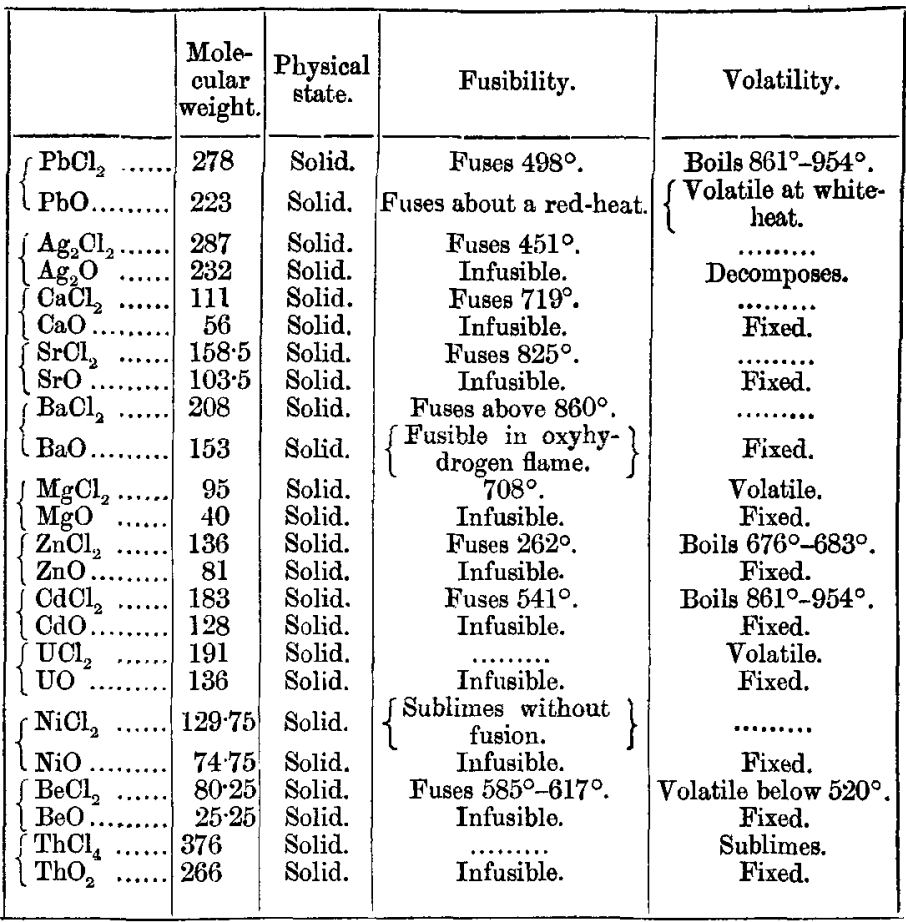

As already stated, this difference in properties is observed especially in the oxides and chlorides of positive elements, and in general in elements having a metallic brightness. It may be noted by the way that it appears to be the greater the higher the atomicity of the metal.

Whatever nay be its meaning, this physical difference is, by its generality, one of the most remarkable facts in statical chemistry, strange and, at first sight, quite exceptional.

The properties of compound bodies do not appear by chance; they are only the final result of the properties of the constituent elements - a result more or less modified in consequenco of the physical phenomena of combination. Chemical compounds are therefore really mixtures of a special kind. It cannot be denied that the properties of compounds are closely related to those of their principal constituents. The differences between certain elements occur again with greater or less fidelity in their corresponding and comparable compounds. That being so, the behaviour of the metallic oxides is especially 
surprising when compared with the chlorides of the same elements.

The difference between the volatility of oxygen and chlorine is enormous. The former, until recently, was considered as a permanent gas ; the other, on the contraty, is easily condensed, and only becomes gaseous at $-33^{\circ} \cdot 6$ (Regnault). An atom of oxygen weighs 16 , and that of chlorine 35.5 . The molecular weights of the chlorides are consequently much greater than those of the corresponding oxides. Now, of mechanical or physical properties, there is not one which is more directly dependent on the molecular weight than fusibility and volatility.

Bearing these facts in mind, we are justified in formulating $\grave{a}$ priori the following propositions:-(1) Oxygen and chlorine are both of them elements which are endowed with great volatility as compared with other elements. The oxides and the chlorides ought, therefore, to be volatile compounds. (2) Volatility exists to a greater degree in oxygen than in chlorine. The oxides ought, therefore, to be more volatile than the corresponding chlorides. The oxides ought frequently to be very volatile, or even gaseous, at the ordinary temperature.

These theoretical deductions are, in fact, realized in a good number of oxygenated and chlorinated compounds, particularly in the case of elements or radicals which are negative or metalloidal, e.g. As, Os, Ru, \&c.

\begin{tabular}{|c|c|c|c|}
\hline & $\begin{array}{c}\text { Mole- } \\
\text { cular } \\
\text { weight. }\end{array}$ & Physical state. & Volatility. \\
\hline 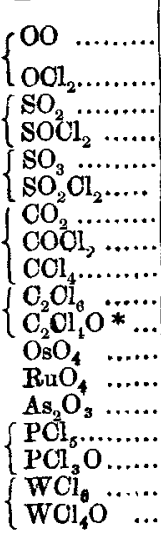 & $\begin{array}{c}32 \\
87 \\
64 \\
119 \\
80 \\
135 \\
44 \\
99 \\
154 \\
237 \\
182 \\
263 \\
168 \\
198 \\
208 \cdot 5 \\
1535 \\
395 \\
342\end{array}$ & $\begin{array}{c}\text { Perfect gas ; formerly } \\
\text { considered permanent. } \\
\text { Gas, easily condensed. } \\
\text { Gas. } \\
\text { Liquid. } \\
\text { Solid. } \\
\text { Liquid. } \\
\text { Gas. } \\
\text { Liquid. } \\
\text { Liquid. } \\
\text { Solid. } \\
\text { Liquid. } \\
\text { Solid. } \\
\text { Solid. } \\
\text { Solid. } \\
\text { Solid. } \\
\text { Liquid. } \\
\text { Solid. } \\
\text { Solid. }\end{array}$ & $\begin{array}{l}\text { Boils }-10^{\circ} . \\
\text { Boils } 82^{\circ} . \\
\text { Boils } 46^{\circ} \text {. } \\
\text { Boils } 82^{\circ} \text {. } \\
\text { Boils }-78^{\circ} \text {. } \\
\text { Boils }+8^{\circ} \text {. } \\
\text { Boils }+76^{\circ} \text {. } \\
\text { Boils } 182^{\circ} \text {. } \\
\text { Boils } 118^{\circ} \text {. } \\
\text { Volatilizes about } 100^{\circ} \text {. } \\
\text { Volatilizes } 100^{\circ} . \\
\text { Volatilizes } 200^{\circ} \text {. } \\
\text { Boils } 148^{\circ}+. \\
\text { Boils } 110^{\circ} . \\
\text { Boils } 346^{\circ} . \\
\text { Boils } 227^{\circ} \text {. }\end{array}$ \\
\hline
\end{tabular}

$* \mathrm{CCI}_{3} \cdot \mathrm{COCl}$.

+ Decomposing into $\mathrm{PCI}_{3}+\mathrm{Cl}_{2}$. 
Relationships of a similar kind, as regards volatility, are observed between the oxides and the chlorides of the bivalent radicals $\mathrm{C}_{n} \mathrm{H}_{2 n}$, which are the most analogous to the metals, for example:-

\begin{tabular}{|c|c|c|c|}
\hline & & $\begin{array}{c}\text { Molecular } \\
\text { weight. }\end{array}$ & Volatility. \\
\hline $\begin{array}{l}\left\{\begin{array}{l}\mathrm{O}_{2} \mathrm{H}_{4} \mathrm{O} \ldots \ldots \\
\mathrm{C}_{2} \mathrm{H}_{4} \mathrm{Cl}_{2} \ldots\end{array}\right. \\
\left\{\begin{array}{l}\mathrm{O}_{3} \mathrm{H}_{8} \mathrm{O} \ldots \ldots \\
\mathrm{C}_{3} \mathrm{H}_{6} \mathrm{Cl}_{2} \ldots\end{array}\right.\end{array}$ & 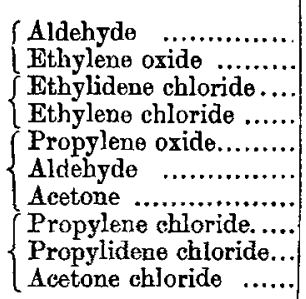 & $\begin{array}{c}44 \\
\ddot{99} \\
\ddot{58} \\
" \\
113 \\
\# \\
\#\end{array}$ & 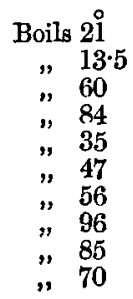 \\
\hline
\end{tabular}

Let us now attempt, by the aid of this general idea, to determine, à priori, what ought to be the properties of certain particularly interesting oxides.

To $\mathrm{CO}_{2}$, which is gaseous at the ordinary temperature and boils at $-78^{\circ}$, corresponds $\mathrm{CCl}_{4}$, which is a liquid boiling at $+76^{\circ}$. The difference in volatility between the two bodies is $154^{\circ}$. $\mathrm{SiCl}_{4}, \mathrm{TiCl}_{4}$, and $\mathrm{SnCl}_{4}$ boil respectively at $58^{\circ}, 136^{\circ}$, and $115^{\circ}$. It might therefore be reasonably supposed that the corresponding oxides should be eminently volatile. $\mathrm{SiO}_{2}$ ought certainly to be gaseous at the ordinary temperature, or at least as gaseous as $\mathrm{SO}_{2}$, to which it is analogous, and the molecular weight of which is but little different.

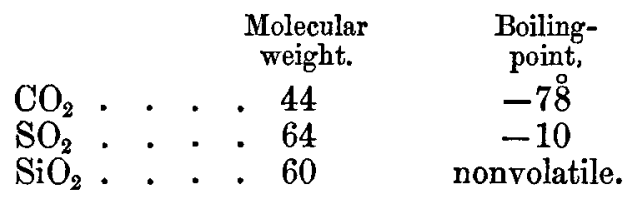

$\mathrm{BCl}_{3}$, with molecular weight $117 \cdot 5$, is a liquid boiling at $18^{\circ} ; \mathrm{B}_{2} \mathrm{O}_{3}$, with molecular weight 70 , ought therefore to be a gas at the ordinary temperature.

$\mathrm{Al}_{2} \mathrm{Cl}_{6}$ is a solid, which volatilizes about $100^{\circ}$, and ought therefore to have a corresponding oxide $\mathrm{Al}_{2} \mathrm{O}_{3}$, if not gaseous, at least very volatile, and the same should hold good as regards $\mathrm{Fe}_{2} \mathrm{O}_{3}$.

$\mathrm{HgCl}_{2}$ (boiling-point $295^{\circ}$ ) should have a corresponding oxide, $\mathrm{HgO}$ (containing a so-called permanent gas in combination with a volatile metal), which, if not gaseous, should at least be much more volatile than $\mathrm{HgCl}_{2}$, or metallic mercury. 
The chromates are analogous to the sulphates both in their general composition and crystallographical properties. One would expect, therefore, that the difference between $\mathrm{CrO}_{2} \mathrm{O}$ and $\mathrm{CrO}_{2} \mathrm{Cl}_{2}$ would be similar to that between $\mathrm{SO}_{2} \mathrm{O}$ and $\mathrm{SO}_{2} \mathrm{Cl}_{2}$. Now $\mathrm{SO}_{3}$ boils at $46^{\circ}$ and $\mathrm{SO}_{2} \mathrm{Cl}_{2}$ at $77^{\circ}$, whilst $\mathrm{CrO}_{2} \mathrm{Cl}_{2}$ is a liquid boiling at $118^{\circ}$; and from analogy we should expect $\mathrm{CrO}_{3}$ to be also a liquid still more volatile, and boiling even below $100^{\circ}$, whereas $\mathrm{CrO}_{3}$ is a solid, fusible only at about $300^{\circ}$. The oxides, in fact, instead of being gaseous at the ordinary temperature, or at least very volatile liquids, as analogy would have led us to expect, are generally solid, and frequently almost infusible. What is the explanation of this fact, so strange in its nature and so important from its generality? I regard no fact, however strange, as abnormal or exceptional. In my opinion anomalies and exceptions have no real existence. They depend most probably, as already stated, on our ignorance of the consequences, under certain conditions, of a general known cause.

\section{The Oxides are not Molecularly Comparable to the Chlorides.}

Polymerization of the Oxides.-The chlorides and oxides are almost universally indicated by formulæ which represent these bodies as molecularly comparable. But are the oxides really comparable with the chlorides of the same elements? Is there a real analogy between them, or is this analogy merely artificial, and dependent solely on the notation employed? These are questions which require examination. The chlorides being compounds which are frequently volatile without decomposition, the formulæ assigned to them have usually been deduced from the determination of their vapour-density; so that these formulæ really represent, both in weight and size, the molecules of these bodies, at least in the gaseous state. This is not the case, however, with the metallic oxides. Being fixed, or volatile only at the very highest temperatures, or else decomposing under the action of heat, their vapour-densities are unknown, and cannot be determined. The formulæ universally attributed to the metallic oxides depend solely on analytical determinations. These formulæ are therefore simply empirical, and merely represent the relations between the weights of the constituent elements, but are perfectly silent as regards the absolute quantities.

The formulæ of the oxides have thus their origin, and rest on an entirely different basis from the formulæ of the chlorides. There is no authority for attributing to both the same value and signification. The relation between the oxides and chlorides, as represented by the usual formulæ, is purely artificial. 
The true oxides $\mathrm{RO}_{x}$, which are really comparable with the known chlorides $\mathrm{RCl}_{2 a}$, are for the most part quite unknown. We only have the polymeric oxides $n\left(\mathrm{RO}_{x}\right)$, in which $n$ is a large number. To make this clear, we may take an example from organic chemistry in illustration, viz. the chlorides of ethylene and ethylidene:-

$$
\begin{array}{ll}
\mathrm{CH}_{3} \\
\stackrel{\mathrm{d}}{\mathrm{CHCl}} \mathrm{HCl}_{2}
\end{array} \text { b.-p. } 60^{\circ}, \quad \begin{aligned}
& \mathrm{CH}_{2} \mathrm{Cl} \\
& \mathrm{CH}_{2} \mathrm{Cl}
\end{aligned} \text { b.-p. } 84^{\circ} .
$$

Not only are the corresponding oxides, acetaldehyde and ethylene oxide,

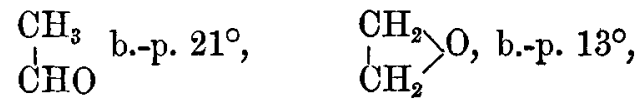

known, but also their respective polymers paraldehyde and metaldehyde, as well as the dioxide and polyoxide of ethylene.

$\left\{\right.$ Paraldehyde . . $\left(\mathrm{C}_{2} \mathrm{H}_{4} \mathrm{O}\right)_{3}$, liquid, boiling-point $124^{\circ}$.

\{Metaldehyde . . $\left(\mathrm{C}_{2} \mathrm{H}_{4} \mathrm{O}\right)_{n}$, solid, nonvolatile as such.

$\left\{\right.$ Ethylene dioxide $\quad\left(\mathrm{C}_{2} \mathrm{H}_{4} \mathrm{O}\right)_{2}$, solid, boiling-point $102^{\circ}:$

$\left\{\right.$ Ethylene polyoxide $\left(\mathrm{C}_{2} \mathrm{H}_{4} \mathrm{O}\right)_{n}$, solid, volatile with difficulty.

This interpretation of oxides being admitted, it is no longer a hypothesis, but a fact, that the physical state and thermal properties, notably the fusibility and volatility, are a direct function of the molecular weight, and every abnormal relation, from the physical point of view, between the chlorides and oxides ceases immediately. The infusibility and fixity of the latter, so strange at first sight, return into the natural order of things.

We have, therefore, to prove the following proposition:-

The known oxides, and notably the metallic oxides, are polymers $n\left(\mathrm{RO}_{x}\right)$ of the true oxides $\mathrm{RO}_{x}$, corresponding to the chlorides $\mathrm{RCl}_{2 x}$.

\section{Proofs of the Polymerization of the Oxides.}

Their Additive Power.-There are no compounds which are more ready to enter into combination than the oxides. In fact, it would not be far from the truth to say that there is no class of compounds with which they are incapable of entering into combination. In mineral chemistry they combine by addition, and often with considerable energy, not only with oxides of a contrary sign-acid oxides with basic oxides,but with all chemical compounds indiscriminately, whatever may be their special function. 
Let as limit ourselves more especially to metallic oxides. They combine not only with the oxides of negative radicals, but also with the most diverse binary compounds-chlorides, bromides, iodides, sulphides, selenides, \&c.; with oxysalts in general-hydrates, sulphates, nitrates, carbonates, \&c., forming the large series of basic salts of the polyvalent metals. These additive compounds are formed in the most varied proportions ; so that the series of basic salts is illimitable. Many of them are marked by a definite composition and by a regular crystalline character; some even occur naturally in the mineral kingdom.

This additive power is observed also, though in a less degree, with the oxides of organic radicals, and notably in the case of the glycollic oxides, $\mathrm{C}_{n} \mathrm{H}_{2 n} \mathrm{O}$, which are so similar in other respects to the metallic oxides $\mathrm{RO}$. The oxide of ethylene combines with its hydrate, glycol $\mathrm{C}_{2} \mathrm{H}_{4}(\mathrm{OH})_{2}$, with acetic anhydride, with acetyl chloride, with the balogen hydracids, \&c. The aldehydes $\mathrm{C}_{n} \mathrm{H}_{2 n+1}$. CHO behave in a similar manner.

But let us return to the metallic oxides. Metallic oxides enter into combinations with other metallic oxides which differ in composition, both in the nature of the metal and in the quantity of oxygen. Thus, $\mathrm{MgO}$ combines with $\mathrm{Al}_{2} \mathrm{O}_{3}$ to form spinelle, $\mathrm{MgO} \cdot \mathrm{Al}_{2} \mathrm{O}_{3}$. Still more remarkable is the combination of two oxides of the same metal, as in magnetic oxide of iron, $\mathrm{FeO} . \mathrm{Fe}_{2} \mathrm{O}_{3}$; red lead, $2 \mathrm{PbO} . \mathrm{PbO}_{2}$; hausmannite, $\mathrm{MnO} . \mathrm{Mn}_{2} \mathrm{O}_{3} ; \mathrm{SnO}$. $\mathrm{SnO}_{2} ;$ \&c.

Organic chemistry also furnishes examples of this, which are still more curious in so far as we have cases where two oxides, equally oxygenated, combine, as in the case of the double oxide of ethylene and ethylidene discovered by Würtz (Bull. Soc. Chim. iv. p. 16), $\left(\begin{array}{l}\mathrm{CH}_{2} \backslash \mathrm{O}+\frac{\mathrm{CHO}}{\mathrm{d}_{2}} \mathrm{CH}_{3} \\ \mathrm{CH}_{2}\end{array}\right)$. Here we have polymerization properly so called.

In the absence of foreign molecular systems on which they can exercise their additive power, oxides, both organic and inorganic, combine with themselves; and in this combination of a body with itself lies the gist of polymerization in its largest sense. This fact may be illustrated by examples from organic chemistry. Ethylene oxide, $\mathrm{CH}_{2} \mathrm{CH}_{2} \backslash \mathrm{O}$, is a colourless liquid, boiling at $13^{\circ}$. Two distinet polymers of this compound are known :-(a) The so-called diethylene dioxide, ${ }_{\mathrm{CH}}^{\mathrm{C}} \mathrm{CH}_{2} \cdot \mathrm{O} \cdot \mathrm{O} \cdot \mathrm{CH}_{2}^{\mathrm{C}} \mathrm{CH}_{2}$, is obtained directly from the monoxide and is a crystalline solid, melting-point $9^{\circ}$, boiling-point $102^{\circ}$. (b) A polymer, $\left(\mathrm{C}_{2} \mathrm{H}_{4} \mathrm{O}\right)^{n}$, obtained by 
Würtz (Compt. Rend. lxxxiii. p. 1141), is formed spontaneously as a white solid crystalline mass, melting-point $56^{\circ}$, and volatile with difficulty.

In connection with this question there is no body more interesting than methylen $\theta$ oxide, $\mathrm{CH}_{2}: \mathrm{O}$. The corresponding chloride, $\mathrm{CH}_{2} \mathrm{Cl}_{2}$, is a liquid, boiling-point $40^{\circ}$. The oxide itself should be naturally a gas, but only assumes this state under the action of heat ; so soon as the heat is withdrawn, it polymerizes, and is converted into a white solid mass which is insoluble in water, and sublimes at $100^{\circ}$, again changing at higher temperatures into the gaseous $\mathrm{CH}_{2} \mathrm{O}$, as indicated by its vapour-density. The aldehydes $\mathrm{C}_{n} \mathrm{H}_{x}$. $\mathrm{CHO}$ are especially characterized by their tendency to polymerization, giving rise to products differing from the original aldehyde in all their physical properties - fusibility, volatility, solubility, \&c. Acetaldehyde may be taken as a type of this class. Under ordinary circumstances it is a liquid, boiling-point $21^{\circ}$. There are two distinct polymers known:-

(a) Paraldehyde is a liquid, boiling-point $124^{\circ}$, and in the state of gas is represented by $\left(\mathrm{C}_{2} \mathrm{H}_{4} \mathrm{O}\right)_{3}$, as proved by its vapourdensity.

(b) Metaldehyde, $\left(\mathrm{C}_{2} \mathrm{H}_{4} \mathrm{O}\right)_{n}$, is a solid, crystallizing in beautiful needles, which sublime at $100^{\circ}$, and volatilize without melting at $112-115^{\circ}$, being transformed again into ordinary aldehyde as indicated by its vapour-density.

Trichloraldehyde, or chloral, $\mathrm{CCl}_{3}$. $\mathrm{CHO}$, polymerizes still more easily. When recently distilled, it is a liquid, boiling at $94-95^{\circ}$; after remaining at rest for some time, it is spontaneously, and sometimes rapidly, converted into what is called insoluble chloral, which is a white, opaque, porcellaneous, hard mass, and, when heated to $180^{\circ}$, re-forms ordinary chloral.

The aldol, $\mathrm{CH}_{3}$. $\mathrm{CH}(\mathrm{OH}) \cdot \mathrm{CH}_{2}$. CHO, of Würtz also polymerizes readily, forming paraldol, which is a beautiful crystalline solid, melting at $90^{\circ}$ (Comptes Rendus, lxxxiii. p. 255). Some aldehydes are only known in the polymeric state, as oxalic aldehyde or glyoxal*, CHO . CHO.

From analogy, this body ought to be gaseous, or at least a very volatile liquid at the ordinary temperature:-

- Given the difference in volatility between the chlorides of the negative radicals and the corresponding aldehydes,

$\mathrm{CH}_{3} . \mathrm{COCl}$, b.-p. $55^{\circ}, \mathrm{CH}_{3} . \mathrm{COH}$, b.-p. $21^{\circ}$,

we should conclude that ordinary succinic aldehyde was a polymer:$\mathrm{COCl} . \mathrm{OH}_{2} \cdot \mathrm{CH}_{2}$. $\mathrm{COCl}$, b.-p. $190^{\circ}$, $\mathrm{COH} . \mathrm{CH}_{2}, \mathrm{CH}_{2}$. COH, b.-p. $201^{\circ}-203^{\circ}$. 


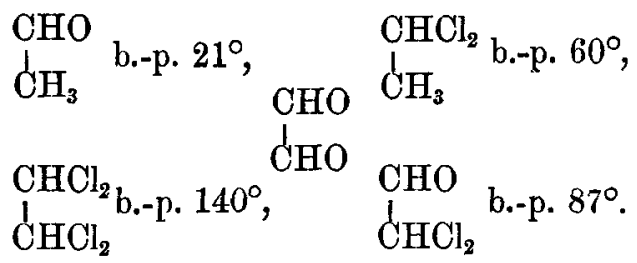

In reality, however, glyoxal is only known as a nonvolatile viscous mass. It is unnecessary to extend these examples, for the same facts are illustrated in various degrees by all the members of this group (see Bruylants, 'On the Polymerization of the Aldehydes,' Inaug. Diss., Louvain, 1875). The self-additive power of methylene oxide, which is so evident in its mono-derivatives, the aldehydes, is less marked in its di-derivatives, the acetones. Though true polymers of acetone itself are unknown, yet those of some of its chloroderivatives have been obtained by Grabowsky (Ber. viii. p. 1438).

If we compare the boiling-points of the glycollic, aldehydic, and acetonic chlorides with those of the corresponding oxides, thus:-

$$
\begin{aligned}
& \mathrm{CH}_{2} \cdot \mathrm{CH}_{2} . \mathrm{O} \ldots \text { b.-p. } \stackrel{\circ}{13} \text {, } \mathrm{CH}_{2} \mathrm{Cl} . \mathrm{CH}_{2} \mathrm{Cl} \ldots \ldots \text {...b.-p. } 84 \\
& \mathrm{CH}_{3} \cdot \mathrm{CHO} \ldots . . ., 21 \\
& \mathrm{CH}_{3} \cdot \mathrm{CH} . \mathrm{CH}_{2} \cdot \mathrm{O}, 35 \\
& \mathrm{CH}_{3} \cdot \stackrel{\mathrm{CH}}{\mathrm{CH}} \cdot \mathrm{CHO}, 47 \\
& \mathrm{CH}_{3} . \mathrm{CO} . \mathrm{CH}_{3} \ldots, \quad, 56 \\
& \mathrm{CH}_{3} \cdot \mathrm{CHCl}_{2} \ldots \ldots \ldots, \quad 60 \\
& \mathrm{CH}_{3} \cdot \mathrm{CHCl} . \mathrm{CH}_{2} \mathrm{Cl}, 96 \\
& \mathrm{CH}_{3} \cdot \mathrm{CH}_{2} \cdot \mathrm{CHCl}_{2}, \quad 85 \\
& \mathrm{CH}_{3} \cdot \mathrm{CCl}_{2} \cdot \mathrm{CH}_{3}, \% 70
\end{aligned}
$$

and if we further bear in mind the general fact that in the isomeric substituted derivatives of the paraffins, the volatility is the greater when the substitution has taken place in a chain or chains which are least hydrogenated, then we must conclude that the aldehydes and acetones are only known to us in the state of polymers, which depolymerize completely at the boiling-point. Thus, acetic aldehyde should be gaseous and more volatile than the oxide of ethylene; propionic aldehyde more volatile than oxide of propylene; and acetone more volatile than the corresponding aldehyde $\mathrm{C}_{3} \mathrm{H}_{6} \mathrm{O}$. The real relations are, however, the reverse of these.

\section{Actual Polymerization of the Oxides themselves.}

The actual polymerization of the oxides is readily indicated by all those characters which have been long observed in the case of the special variety of oxides called by Chevreul " oxydes cuits." Certain anhydrous and pulverulent metallic oxides, 
obtained by dehydration of their hydroxides at as low a temperature as possible, suddenly enter into vivid incandescence when exposed to a higher temperature, verging on redness. Their properties are thus modified both physically and chemically; they become denser, harder, and, when coloured, their colour is intensified. 'l'hey show a greater resistance to the action of chemical agents than in their former condition, some even entirely resisting the action of acids and alkalies. $\mathrm{Fe}_{2} \mathrm{O}_{3}, \mathrm{Cr}_{2} \mathrm{O}_{3}, \mathrm{ZrO}_{2}$, \&c., are examples. The fact of this vivid incandescence, which is not accompanied by any alteration in the composition of the product, is the manifest proof of an energetic combination of the oxide with itself. When hydrocarbons, such as amylene, terebenthene, \&c., are polymerized under the action of certain agents, such as sulphuric acid, and especially boron fluoride, a development of heat takes place which is frequently considerable. Finally, arsenic trioxide is a direct proof of accumulation in a single molecule, even in the gaseous state, of several normal molecules corresponding to the chloride. Arsenic trichloride being $\mathrm{AsCl}_{3}$, the corresponding oxide ought to be $\mathrm{As}_{2} \mathrm{O}_{3}$. This is in fact the arsenical oxygenated compound which is present in the arsenites of methyl and ethyl (Bull. Soc. Chim. xiv. p. 101), compounds which are volatile without decomposition, and whose formulæ, as deduced from vapour-density determinations, are $\left(\mathrm{CH}_{3}\right)_{3} \mathrm{AsO}_{3}$ and $\left(\mathrm{C}_{2} \mathrm{H}_{5}\right)_{3} \mathrm{AsO}_{3}$. The molecule of arsenious oxide in the gaseous state corresponds not to $\mathrm{As}_{2} \mathrm{O}_{3}$, but to $\left(\mathrm{As}_{2} \mathrm{O}_{3}\right)_{2}$ or $\mathrm{As}_{4} \mathrm{O}_{6}$, as proved by its vapour-density. It volatilizes at about $200^{\circ}$ without fusion; and there can be no doubt that its molecule in the solid state is some multiple of its gaseous molecule $\mathrm{As}_{4} \mathrm{O}_{6}$. There is thus established between the methylenic compounds and the arsenious ethers a complete parallel. To this we shall refer again.

\section{Various Methods of Producing the Oxides.}

By Dehydration of the Hydroxides.-The various methods of obtaining the oxides from other compounds containing them as radicals also tend to show that they are polymers. Among these methods, one of the most important, on account of its generality, and also the most interesting from our particular point of view, is the dehydration of hydroxides. Under the action of heat the hydroxides, with but few exceptions, lose water, either wholly or partially. But, however this may be, the dehydration is the more complete the higher the temperature. This temperature varies according to the nature of the hydroxide. Some of the latter have only an ephemeral existence at the ordinary temperature, and are therefore more 
usually represented by their anhydrides. In addition to these general facts, it is important to observe not only the nature of the anhydrides thus obtained, but also the connection which underlies the two distinct chemical phenomena, viz. dehydration and molecular condensation. Würtz developed this principle in one of his lectures before the Chemical Society of Paris in 1863. The elimination of water usually depends not on one but on several molecules of the hydroxide, the residues of which become soldered together, as it were, by the atoms of oxygen; we therefore get an accumulation of the radicals of these hydroxides in the products formed-a veritable molecular condensation proportional to this accumulation. This principle applies to all hydroxides indiscriminately, not only to the normal hydroxides $\mathrm{R}^{x}(\mathrm{OH})_{x}$, but to the oxyhydroxides or incomplete anhydrides $\mathrm{R}^{x} \mathrm{O}_{n}(\mathrm{OH})_{x \rightarrow 2 n}$. It therefore follows that the compounds formed under these conditions become more and more complex, in proportion as this dehydration itself is more or less complete.

These general facts apply to all hydroxides, both organic and mineral. The following are illustrations from organic chemistry:-

The acid alcohols are the most interesting in this connection. The most simple, and therefore the most conclusive cases are furnished by the glycollic and lactic acids. When heated, these compounds lose successively a half and then a whole molecule of water, forming finally glycollide and lactide. I have shown (Bull. Acad. Belg. xxvii. p. 409) that lactide in the state of vapour ought to be represented by the formula $\left[\left(\mathrm{C}_{3} \mathrm{H}_{4} \mathrm{O}\right) \mathrm{O}\right]_{2}$, and not by the usual formula $\left(\mathrm{C}_{3} \mathrm{H}_{4} \mathrm{O}\right) \mathrm{O}$. The same thing applies also to glycollide, which is nonvolatile. If we represent the radicals glycollyl $\left(\mathrm{C}_{2} \mathrm{H}_{2} \mathrm{O}\right)$ and lactyl $\left(\mathrm{C}_{3} \mathrm{H}_{4} \mathrm{O}\right)$ respectively by $\mathrm{Gl}$ and $\mathrm{La}$, the action of heat on glycollic and lactic acids will be expressed thus*:-<smiles>O[Hg]O</smiles><smiles>OC(O)O</smiles><smiles>O[SiH2]O</smiles><smiles></smiles><smiles>O1O[AlH]O1</smiles>

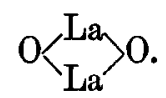

- The following considerations prove that glycollide cannot be $\mathrm{C}_{2} \mathrm{H}_{2} \mathrm{O}_{2}$, but is really a polymer $\left(\mathrm{C}_{2} \mathrm{H}_{2} \mathrm{O}_{2}\right)_{n}$. The minimum molecule of glycollic acid is represented by $\mathrm{CH}_{2} \mathrm{OH}$. $\mathrm{COOH}$, and contains therefore the tetravalent radical $\left(\equiv \mathrm{C} . \mathrm{CH}_{2}-\right.$ ). The corresponding chloride $\mathrm{CCl}_{3} . \mathrm{CH}_{2} \mathrm{Cl}$ is a liquid, b.-p. $102^{\circ}$. Consequently the oxide, or glycoll, $\mathrm{O}=\mathrm{C} . \mathrm{CH}_{2} . \mathrm{O}$, ought to be still more volatile, just as the oxide of methylene is gaseous, whilst the chloride $\mathrm{CH}_{2} \mathrm{Cl}_{2}$ is a liquid, b.-p. $40^{\circ}$. In reality, however, this is not the case, for glycollide is a fixed solid. 
Ethylenic hydroxide, $\mathrm{CH}_{3} \cdot \mathrm{C}(\mathrm{OH})_{3}$ (or acetic acid, $\mathrm{C}_{2} \mathrm{H}_{4} \mathrm{O}_{2}+\mathrm{H}_{2} \mathrm{O}$ ), when distilled, is dehydrated, and forms the corresponding oxybydroxide (i. e. the cormmon acetic acid), which is represented in the state of vapour, not by the formula $\mathrm{C}_{2} \mathrm{H}_{4} \mathrm{O}_{2}$ or $\mathrm{CH}_{3}$. CO. OH, but by $\left(\mathrm{C}_{2} \mathrm{H}_{4} \mathrm{O}_{2}\right)_{2}$ or

$$
\mathrm{CH}_{3} \cdot \underset{\mathrm{O}(\mathrm{OH})}{\mathrm{C}} \mathrm{O} \cdot \mathrm{C}(\mathrm{OH}) \cdot \mathrm{CH}_{3} \cdot
$$

Again, the transformation on prolonged distillation at the ordinary pressure of certain polyatomic hydroxides, notably glycerol, $\mathrm{C}_{3} \mathrm{H}_{5}(\mathrm{OH})_{3}$, and its monochlorhydrines, $\mathrm{C}_{3} \mathrm{H}_{5}(\mathrm{OH})_{2} \mathrm{Cl}$, into condensation-products by dehydration are further examples of this fact.

Returning now to the dehydration of mineral hydroxides, we have examples in the case of the acid hydroxides.

1. Phosphoric Acid, $\mathrm{H}_{3} \mathrm{PO}_{4}$ or $\left(\mathrm{HO}_{3}\right) \mathrm{PO}$, when heated to $200^{\circ}$, is converted into pyrophosphoric acid, $\mathrm{H}_{4} \mathrm{P}_{2} \mathrm{O}_{7}$ or $(\mathrm{HO})_{2} \mathrm{PO} . \mathrm{O} . \mathrm{PO}(\mathrm{OH})_{2}$. Note also, in passing, the various modifications of condensed metaphosphoric acid, discovered by Fleitmann and Henneberg.

2. Boric Acid, when dry and crystalline, is represented by $\mathrm{H}_{3} \mathrm{BO}_{3}$. On heating, it dehydrates progressively as follows:-

Dried at ordinary temperature $\quad \mathrm{H}_{3} \mathrm{BO}_{3}$.

$$
\begin{aligned}
& \text {, } 100^{\circ} \text {..... . . } \mathrm{HBO}_{2} \text { or } \mathrm{H}_{2} \mathrm{~B}_{2} \mathrm{O}_{4} \text {. } \\
& " 160^{\circ} \text {. . . . . . . } \mathrm{H}_{2} \mathrm{~B}_{4} \mathrm{O}_{7} \text {. } \\
& \text { " } 270^{\circ} \text {. . . . . . } \mathrm{H}_{2} \mathrm{~B}_{16} \mathrm{O}_{25} \text {. }
\end{aligned}
$$

At higher temperatures there is total dehydration and formation of fused anhydride $\left(\mathrm{B}_{2} \mathrm{O}_{3}\right)_{n}$.

3. Silicic Acid.-Normal silicic acid, $\mathrm{H}_{4} \mathrm{SiO}_{4}$, is searcely known as such. It no donbt forms the gelatinous silica when froshly precipitated. When heated, it exhibits progressive dehydration:-

Dried at ordinary temperature $\mathrm{H}_{2} \mathrm{SiO}_{3}$ or $\mathrm{H}_{4} \mathrm{Si}_{2} \mathrm{O}_{6}$.

$$
\begin{aligned}
& \text { " } 20^{\circ}-25^{\circ} \text {. . . . } \mathrm{H}_{2} \mathrm{Si}_{2} \mathrm{O}_{5} \text {. } \\
& \text { " } 60^{\circ} \text {. . . . . . } \mathrm{H}_{2} \mathrm{Si}_{3} \mathrm{O}_{7} \text {. } \\
& \text { " } 80^{\circ}-100^{\circ} \text {. . . . . } \mathrm{H}_{2} \mathrm{Si}_{4} \mathrm{O}_{9} \text {. } \\
& \text { " } 250^{\circ}-270^{\circ} \text {. . . . . } \mathrm{H}_{2} \mathrm{Si}_{8} \mathrm{O}_{17} \text {. }
\end{aligned}
$$

After which, total dehydration with formation of $\left(\mathrm{SiO}_{2}\right)_{n}$.

4. Titanic Acid.

Dried at ordinary temperature - $\mathrm{H}_{4} \mathrm{TiO}_{4}$.

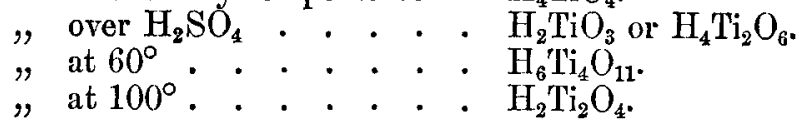

Also similarly with molybdic and stannic hydrates.

Plill. Mag. S. 5. Vol. 20. No. 123. August 1885. 
It is well to state here that I do not attach an absolute value to the formulæ attributed to a good number of these incomplete hydrates of mineral acids. It would be difficult to regard all of them as definite compounds. The fact which is in evidence, and with which alone wo are at present concerned, is that with rise of temperature the dehydration goes on, and the molecular composition becomes more and more complicated by the accumulation of radicals in the oxyhydroxyl residue. Though these hydrates themselves may not always have the character of well-defined compounds, they are often represented by corresponding derivatives having all the characteristics of true chemical substances.

It is sufficient to mention Troost and Hautefeuille's oxychlorides of silicon, the numerous polysilicates, so varied in composition and often so well defined, the condensed metaphosphates, the molybdates, \&c. Certain anhydrides, which are totally wanting in oxyhydroxides, are represented by welldefined salts, as in the case of chromic acid, of which tho biand tri-chromates, $\mathrm{R}_{2} \mathrm{Cr}_{2} \mathrm{O}_{7}$ and $\mathrm{R}_{2} \mathrm{Cr}_{3} \mathrm{O}_{10}$, are well known. Metallic hydroxides also behave like the acid hydroxides, thus :-

1. Normal Plumbous Hydroxide should be $\mathrm{Pb}(\mathrm{OH})_{2}$, but as ordinarily produced it is already partially dehydrated. Dried at a low temperature, it has the formula $\dot{\mathrm{H}}_{2} \mathrm{~Pb}_{2} \mathrm{O}_{3}$ (Tünnermann, Schaffner, \&c.) or $\mathrm{H}_{2} \mathrm{~Pb}_{3} \mathrm{O}_{4}$, in the form of minute crystalline grains (Payen). At $100^{\circ}$ it loses all its water.

2. Hydrates of Copper-Cupric hydrate, $\mathrm{Cu}(\mathrm{OH})_{2}$, is the bluish precipitate obtained on adding very dilute alkalies to solutions of cupric salts. Heated in water, this hydroxide dehydrates partially and becomes black. It then has the following composition :-

Dried over sulphuric acid . . $\mathrm{H}_{2} \mathrm{Cu}_{3} \mathrm{O}_{4}$ (Harms). , at $100^{\circ}$. . . . . . $\mathrm{H}_{2} \mathrm{Cu}_{6} \mathrm{O}_{7}$ (Rose).

Normal cuprous hydrate would have the minimum formula $\mathrm{Cu}_{2}(\mathrm{OH})_{2}$. On partial dehydration it gives $\mathrm{H}_{2}\left(\mathrm{Cu}_{2}\right)_{8} \mathrm{O}_{9}$ (Millon and Commaille), and $\mathrm{H}_{2}\left(\mathrm{Cu}_{2}\right)_{4} \mathrm{O}_{5}$ (Mitscherlich).

3. Hydrates of Thorium.-One of the known hydrates, dried at $100^{\circ}$, corresponds to $\mathrm{H}_{4} \mathrm{ThO}_{4}$; another, obtained by a different method, and dried at the same temperature, corresponds to $\mathrm{H}_{2} \mathrm{Th}_{4} \mathrm{O}_{9}$ (Clere).

4. Manganic Hydrates.--Several hydroxides, formed under various conditions, correspond to the peroxide $\mathrm{MnO}_{2}$, and are as follows:- $\mathrm{H}_{2} \mathrm{MnO}_{3}, \mathrm{H}_{2} \mathrm{Mn}_{2} \mathrm{O}_{4}, \mathrm{H}_{2} \mathrm{Mn}_{3} \mathrm{O}_{7}, \mathrm{H}_{2} \mathrm{Mn}_{4} \mathrm{O}_{9}$, and $\mathrm{H}_{4} \mathrm{Mn}_{3} \mathrm{O}_{3}$. All these dehydrate, when heated, forming $\mathrm{MnO}_{2}$. 
5. Ferric Hydrates. - The following hydrates of ferric oxide, $\mathrm{Fe}_{2} \mathrm{O}_{3}$, are known:-

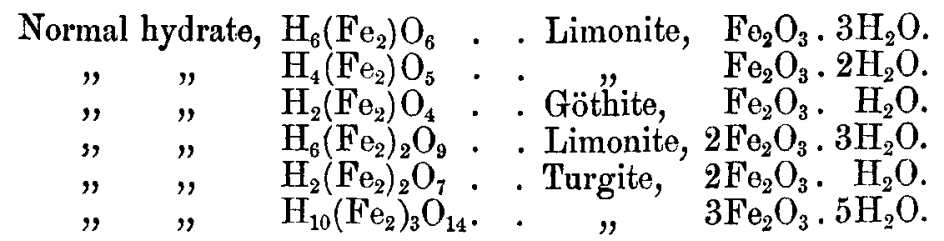

On heating, they are all dehydrated to $\mathrm{Fe}_{2} \mathrm{O}_{3}$.

The brown ocbreous precipitate obtained on adding an alkali to ferric chloride is undoubtedly $\mathrm{Fe}_{2}(\mathrm{OH})_{6}$, but when dried in a vacuum it has the composition $\left(\mathrm{Fe}_{2}\right)_{2} \mathrm{H}_{6} \mathrm{O}_{9}$, or $2 \mathrm{Fe}_{2} \mathrm{O}_{3} \cdot 3 \mathrm{H}_{2} \mathrm{O}$. Heated to ebullition, it dehydrates and becomes $\mathrm{Fe}_{2} \mathrm{H}_{2} \mathrm{O}_{4}$ or $\mathrm{Fe}_{2} \mathrm{O}_{3} . \mathrm{H}_{2} \mathrm{O}$. By prolonged ebullition it can be totally dehydrated.

6. Aluminium Hydrates.-Aluminium solutions, on addition of ammonia in excess, give the normal hydrate $\mathrm{Al}_{2}(\mathrm{OH})_{6}$ in the form of a white gelatinous precipitate. On prolonged ebullition this is partially dehydrated, like the corresponding ferric hydrate, and becomes insoluble in acids and in alkalies, like calcined alumina (Péan de St. Gilles). This new hydroxide corresponds to the formula (HO) ${ }_{2} \mathrm{Al}_{2} . \mathrm{O} \cdot \mathrm{Al}_{2}(\mathrm{OH})_{2}$, which is analogous to pyrophosphoric acid. Besides the normal hydrate $\mathrm{Al}_{2}(\mathrm{OH})_{6}$, hydrargillite, there is also the mineral diaspore, $\mathrm{Al}_{2} \mathrm{O}_{2}(\mathrm{OH})_{2}$ or $\mathrm{Al}_{2} \mathrm{O}_{3} \cdot \mathrm{H}_{2} \mathrm{O}$, to which we shall refer hereafter.

All these oxyhydroxides, both natural and artificial, which are products of the condensation of the normal hydrates, are completely dehydrated under the action of heat, at a temperature above that at which they are formed.

Since the same causes produce the same effects, it is natural to conclude that the last phase of the dehydration is accompanied, as in those which precede it, by an analogous molecular condensation. The elimination of water having determined the accumulation of the radicals in the products to which they give rise, it would bo unreasonable and illogical to suppose that an entirely different phenomenon occurred at the moment of elimination of the last molecule of water, resulting in the dislocation of these residues of condensation previously soldered together by the intermediatory oxygen.

Dehydration and condensation are intimately connected. We must conclude, therefore, that at the moment the last molecule of water is given off, not only does the previous condensation of the oxylydroxide remain, but that, conformably to the genoral rule, it becomes still more accentuated. 
Thus, when crystalline plumbous hydrate, $3 \mathrm{PbO} \cdot \mathrm{H}_{2} \mathrm{O}$, loses its last molecule of water under the action of heat, it is not $\mathrm{PbO}$ which is formed, but at least $(3 \mathrm{PbO})_{2}$. When $\mathrm{H}_{2} \mathrm{Si}_{8} \mathrm{O}_{17}$ becomes the anhydride, we do not get $\mathrm{SiO}_{2}$, but at least $\left(\mathrm{Si}_{8} \mathrm{O}_{16}\right)_{2}$. For a similar reason metaphosphoric acid cannot be $\mathrm{HPO}_{3}$, but is at least $\left(\mathrm{HPO}_{3}\right)_{2}$, since it is formed by dehydration of $\mathrm{H}_{4} \mathrm{P}_{2} \mathrm{O}_{7}$.

The structure of these oxyhydroxides leads to the conclusion that they are, in effect, fragments of the normal hydroxides, $\mathrm{R}^{x}(\mathrm{OH})_{x}$, linked together by atoms of oxygen, thus :-

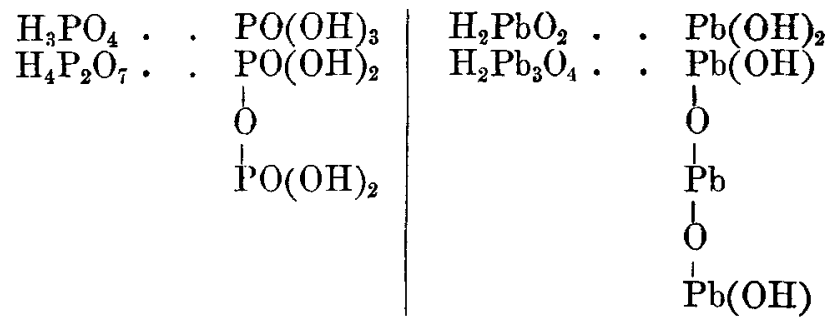

The fact of the polymerization of an oxide at the moment of dehydration of the corresponding hydroxide, is also confirmed experimentally in certain cases, thus :-The methylic and ethylic arsenites $\left(\mathrm{CH}_{3}\right)_{3} \mathrm{AsO}_{3}$ and $\left(\mathrm{C}_{2} \mathrm{H}_{5}\right)_{3} \mathrm{AsO}_{3}$ are decomposed by water, and give, not arsenious acid, $\mathrm{H}_{3} \mathrm{AsO}_{3}$, but the solid anhydride, which is, even in the state of vapqur, a polymer represented by $\mathrm{As}_{4} \mathrm{O}_{6}$.

The same thing also holds good with methylene oxide. Its chloracetate, $\mathrm{CH}_{2} \mathrm{Cl} . \mathrm{OAc}$ (Henry, Bull. Acad. Belg. xxxv. p. 717), its diacetate, $\mathrm{CH}_{2}(\mathrm{OAc})_{2}$, and the compounds obtained by Friedel (Compt. Rend. lxxxv. p. 2471) are also decomposed by water, yielding, not the hydroxide $\mathrm{CH}_{2}(\mathrm{OH})_{2}$, but the solid polymerized oxide $\left(\mathrm{CH}_{2}: \mathrm{O}\right)_{x}$.

The metallic oxides can be obtained from their different salts by various reactions. These general methods furnish a number of facts which tend to prove the polymeric nature of these compounds. We will examine successively in this connection the various classes of salts, such as carbonates, sulphates, \&c.

Carbonates. - As a general rule most carbonates are decomposed by heat, leaving an oxide. For this reason these salts are perfectly assimilable to the hydroxides, and we may therefore confirm by their help the results previously arrived at. The chief difference is the degree of heat required.

It is important, from our point of view, to show that de- 
carbonation, like dehydration, does not occur all at once, but is continuous and progressive according to the temperature. The course of this decomposition is clearly shown in particular cases, notably in the decomposition of certain insoluble carbonates in the presence of water, and at a slightly elevated temperature, and often at the moment of precipitation. The decomposition results in the formation of basic carbonates, anhydrides or hydrates, oxy- or hydroxy-carbonates, of a composition more or less complex, and in the smallest molecule of which are accumulated several molecules of metallic oxide or hydroxide. A large number of metals, e.g. $\mathrm{Mg}, \mathrm{Zn}, \mathrm{Pb}, \mathrm{Cu}$, $\mathrm{Bi}, \mathrm{Hg}, \mathrm{Al}, \mathrm{Cr}, \mathrm{Fe}, \mathrm{Co}, \mathrm{Ni}$, \&c., furnish remarkable examples of this general fact. These insoluble basic carbonates are usually obtained by precipitation with soluble carbonates, either from hot or cold metallic solutions. The composition of these precipitates for the same metal, frequently varies between more or less wide limits, depending on the special circumstances under which the precipitation has taken place. It is evident that these various compounds cannot all be considered as well defined. There are some however, the chemical individuality of which has been well established, and a number of these, either natural or artificial, are capable of assuming the crystalline state. The following are examples :-

$$
\text { a. } \mathrm{Mg} \cdot \quad \cdot \quad \begin{aligned}
& 3 \mathrm{CO}_{2} \cdot 4 \mathrm{MgO}+4 \mathrm{H}_{2} \mathrm{O} . \\
& 4 \mathrm{CO}_{2} \cdot 5 \mathrm{MgO}+5 \mathrm{H}_{2} \mathrm{O} . \text { Magnesia alba. }
\end{aligned}
$$

b. Zn. Composition very varied.

$$
\begin{aligned}
& \mathrm{ZnCO}_{3} . \mathrm{Zn}(\mathrm{OH})_{2}+2 \mathrm{H}_{2} \mathrm{O} . \\
& 2 \mathrm{ZnCO} \\
& 2 . \mathrm{Zn}(\mathrm{OH})_{2} .
\end{aligned}
$$$$
2 \mathrm{ZnCO}_{3} .3 \mathrm{Zn}(\mathrm{OH})_{2} \text {. Crystalline. }
$$$$
4 \mathrm{ZnCO}_{3} .7 \mathrm{Zn}(\mathrm{OH})_{2}+\mathrm{H}_{2} \mathrm{O} \text { (the preceding dried at } 100^{\circ} \text { ). }
$$$$
3 \mathrm{ZnCO}_{3} .5 \mathrm{Zn}(\mathrm{OH})_{2}+\mathrm{H}_{2} \mathrm{O} \text {. }
$$$$
\mathrm{ZnCO}_{3} \cdot 2 \mathrm{Zn}(\mathrm{OH})_{2}+\mathrm{H}_{2} \mathrm{O} \text { (natural). }
$$$$
\mathrm{ZnCO}_{3} \cdot 3 \mathrm{ZnO}+2 \mathrm{H}_{2} \mathrm{O} \text {. }
$$$$
\mathrm{ZnCO}_{3} \cdot 7 \mathrm{ZnO}+2 \mathrm{H}_{2} \mathrm{O} \text {. }
$$

c. $\mathrm{Pb}$. The following, according to $\mathrm{H}$. Rose, represent the composition of the hydrocarbonates of lead formed under definite conditions :-

$$
\begin{aligned}
& 6 \mathrm{PbCO}_{3} \cdot \mathrm{Pb}(\mathrm{OH})_{2}+\mathrm{H}_{2} \mathrm{O}\left\{\begin{array}{l}
\text { by mixing cold and concen- } \\
\text { trated solutions of sodium } \\
\text { carbonate and lead nitrate in } \\
\text { equivalent quantities. }
\end{array}\right. \\
& 5 \mathrm{PbCO}_{3} \cdot \mathrm{Pb}(\mathrm{OH})_{2} \text {. . . ditto, but dilute and cold. } \\
& 3 \mathrm{PbCO}_{3} \cdot \mathrm{Pb}(\mathrm{OH})_{2} \text {. . . ditto, but dilute and boiling. } \\
& 2 \mathrm{PbCO}_{3} \cdot \mathrm{Pb}(\mathrm{OH})_{2} \text {. . . ditto, but with excess of alka- } \\
& \text { line carbonate. }
\end{aligned}
$$


d. Cu. Two basic hydrocarbonates of copper are natural compounds, viz. malachite and azurite, but both may be produced artificially.

$$
\begin{gathered}
\mathrm{CuCO}_{3} \cdot \mathrm{CuO} \cdot 2 \mathrm{H}_{2} \mathrm{O} \\
\mathrm{CuCO}_{3} \cdot \mathrm{CuO} \cdot \mathrm{H}_{2} \mathrm{O} \text { (Malachite). } \\
2 \mathrm{CuCO}_{3} \cdot \mathrm{CuO} \cdot \mathrm{H}_{2} \mathrm{O} \text { (Azurite). }
\end{gathered}
$$

e. Co and Ni.

$$
\begin{aligned}
& 2 \mathrm{CoCO}_{3} \cdot 2 \mathrm{Co}(\mathrm{OH})_{2}+5 \mathrm{H}_{2} \mathrm{O}\left\{\begin{array}{c}
\text { by precipitating a cobalt salt } \\
\text { by alkali carbonate in the } \\
\text { cold. }
\end{array}\right. \\
& 2 \mathrm{CoCO}_{3} \cdot 3 \mathrm{Co}(\mathrm{OH})_{2}+\mathrm{H}_{2} \mathrm{O}\left\{\begin{array}{c}
\text { the preceding precipitate } \\
\text { after washing at a boiling } \\
\text { heat. }
\end{array}\right. \\
& \mathrm{CoCO}_{3} \cdot 3 \mathrm{Co}(\mathrm{OH})_{2}+\mathrm{H}_{2} \mathrm{O}\left\{\begin{array}{c}
\text { the same boiled with carbo- } \\
\text { nate of soda, \&c. }
\end{array}\right. \\
& 2 \mathrm{NiCO}_{3} \cdot 3 \mathrm{Ni}(\mathrm{OH})_{2}+2 \mathrm{H}_{2} \mathrm{O}\left\{\begin{array}{c}
\text { by precipitating nickel sul- } \\
\text { phate with sodium carbo- } \\
\text { nate in the cold. }
\end{array}\right.
\end{aligned}
$$

As a general rule these precipitates become more and more basic as the temperature of precipitation is higher, and, like the corresponding hydrates, they become decarbonated and dehydrated under a more or less intense heat. The cause which determines the molecular complexity of these compounds, the accumulation of the metallic radicals in the same product, leads as a final result to a true oxide. The production of a simple monometallic oxide $\mathrm{RO}_{x}$ by the action of heat, would consequently compel us to assume, that at a given moment an effect was produced quite contrary to all that had preceded it.

Nitrates, Sulphates, and Chlorides.-The following phenomena are quite analogous to that which we have just examined. We have seen that certain carbonates, formed in the presence of water, are partially decomposed by the latter, with the formation of a hydroxide, and the final production of a basic hydrocarbonate, the radical $\mathrm{CO}_{3}$ being replaced by $\mathrm{HO}$. The nitrates, sulphates, and chlorides of certain metals, notably those whose oxides are feeble bases, undergo a similar change in the presence of water. A salt originally neutral in composition is first converted into a basic salt, and finally, under the action of heat, in the presence of a large quantity of water (either alone or slightly alkaline), into a true oxide. Thus :-

Mercuric Nitrate $\mathrm{Hg}\left(\mathrm{NO}_{3}\right)_{2}$, under the action of cold water, gives a basic trimercuric nitrate $\mathrm{Hg}\left(\mathrm{NO}_{3}\right)_{2} \cdot 2 \mathrm{HgO}$, which 
is a yellow salt, known as turbith nitveux. By prolonged treatment with water this salt becomes more and more basic. Kane has described a salt having the composition $\mathrm{Hg}\left(\mathrm{NO}_{3}\right)_{2}$. $5 \mathrm{HgO}$. Finally it gives mercuric oxide. Nitrate of bismuth behaves in a similar manner. A large quantity of water, hot or cold, converts mercuric sulphate, $\mathrm{HgSO}_{4}$, into trimercuric sulphate, $\mathrm{HgSO}_{4} \cdot 2 \mathrm{HgO}$, which, in the presence of an alkaline solution, finally becomes mercuric oxide. The solution of oxide of antimony in fuming sulphuric acid yields, according to Peligot, the crystalline salt $\mathrm{Sb}_{2} \mathrm{O}_{3} \cdot 2 \mathrm{SO}_{3}$. The latter in the presence of water gives the basic salt $\mathrm{H}_{2} \mathrm{SO}_{4} \cdot 2 \mathrm{Sb}_{2} \mathrm{O}_{3}$, which completely decomposes in the presence of a large quantity of water into oxide of antimony. Antimony trichloride, $\mathrm{SbCl}_{3}$, gives, when treated with water, white precipitates of oxychlorides, which are finally converted into the oxide. One of these compounds is crystalline, and has the formula $5 \mathrm{Sb}_{2} \mathrm{O}_{3} \cdot 2 \mathrm{SbCl}_{3}$. It is well known with what facility oxide and chloride of mercury combine to form oxychlorides $(\mathrm{HgO})_{x} \cdot\left(\mathrm{HgCl}_{2}\right)_{y}$. These can be obtained in different ways, and are of very varied composition. Several of them are crystalline, one of the latter being $6 \mathrm{HgO} . \mathrm{HgCl}_{2}$. They are all converted into mercuric oxide in alkaline solution.

It is only natural to suppose that, when these various basic compounds are converted, either by the action of water alone, or in the presence of an alkali, into the oxide, with the total elimination of the acid radical and its replacement by oxygen, the bonds, which hold together the several radicals or atoms of the metal in one and the same molecule, remain throughout. The action of the water having originally determined them, it would be illogical to suppose that at a particular moment they cease to act.

Acid Anhydrides.-The same reasoning may be applied to anhydro-compounds produced by the action of strong acids on their salts, and especially on their acid anhydrides, as in the case of the chromates.

Chromic anhydride, $\mathrm{Cr}_{3}$, forms three series of salts :-

$$
\begin{aligned}
& \text { Monochromates . } \mathrm{K}_{2} \mathrm{CrO}_{4} \text { or } \mathrm{K}_{2} \mathrm{O} . \mathrm{CrO}_{3} \text {. } \\
& \text { Dichromates . . } \mathrm{K}_{2} \mathrm{Cr}_{2} \mathrm{O}_{7} \text { or } \mathrm{K}_{2} \mathrm{O} .2 \mathrm{CrO}_{3} \text {. } \\
& \text { Trichromates . . } \mathrm{K}_{2} \mathrm{Cr}_{3} \mathrm{O}_{10} \text { or } \mathrm{K}_{2} \mathrm{O} .3 \mathrm{CrO}_{3} \text {. }
\end{aligned}
$$

Under the action of an acid, such as sulphuric, the monochromate is converted successively into the di- and tri-chromates, and finally into the anhydride. The latter ought, therefore, to be represented by some multiple of $\mathrm{CrO}_{3}$.

Finally, we find a direct proof of this polymerization in the decomposition of the arsenites by acids. Among these salts 
there are some which contain several molecules of $\mathrm{As}_{2} \mathrm{O}_{3}$ in their molecule, such as :-

$$
\begin{aligned}
& \mathrm{K}_{2} \mathrm{O} \cdot\left(\mathrm{As}_{2} \mathrm{O}_{3}\right)_{2} \cdot \mathrm{H}_{2} \mathrm{O} . \\
& \mathrm{K}_{2} \mathrm{O} \cdot\left(\mathrm{As}_{2} \mathrm{O}_{3}\right)_{2} \cdot \\
& 2 \mathrm{~K}_{2} \mathrm{O} \cdot\left(\mathrm{As}_{2} \mathrm{O}_{3}\right)_{3} \cdot 3 \mathrm{H}_{2} \mathrm{O} .
\end{aligned}
$$

All these salts, under the action of acids, give arsenious anhydride, which, even in the state of vapour, is represented by $\left(\mathrm{As}_{2} \mathrm{O}_{3}\right)_{2}$. Here we have a proof of the accumulation of radicals, which exists in the primitive salt, remaining in the expelled oxide.

\section{Comparative Density of Oxides.}

A comparison of the specific gravities of the metallic oxides with those of other compounds, containing the same radical, furnishes a new argument for the polymerization of the oxides.

The specific gravity of a solid body doubtless depends in a great measure on the state of aggregation, and is also ultimately connected with the composition of the body and the size of the molecular weight. This connection becomes evident in the case of isomorphous solid bodies, which differ by elements of which the atomic weights are very far apart as to their numerie value.

The density, then, is to a certain degree a function of the molecular weight. If the oxides corresponding to the normal hydrates, less water, be represented by

$$
\mathrm{R}^{x}(\mathrm{OH})_{x}=\mathrm{R}^{x} \mathrm{O}_{\frac{x}{z}}-\frac{x}{2} \mathrm{H}_{2} \mathrm{O},
$$

it follows that, having a smaller molecular weight than the hydroxides, their density in the solid state should also be less

\begin{tabular}{|c|c|c|}
\hline & $\begin{array}{c}\text { Molecular } \\
\text { weight. }\end{array}$ & Density. \\
\hline 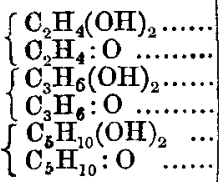 & $\begin{array}{r}62 \\
45 \\
76 \\
59 \\
104 \\
87\end{array}$ & $\begin{array}{l}1.126 \text { at } 0^{\circ} \\
0.898 ", \\
1.051 " \\
0.859 " \\
0.987 " \\
0.824 "\end{array}$ \\
\hline
\end{tabular}
than that of the latter. This is in fact the relation which is observed between the glycols and their anhydrides, which latter are the oxides of the radicals $\mathrm{C}_{n} \mathrm{H}_{2 n}$, thus :-

A difference of an exactly inverse order exists between the 
metallic hydrates and their anhydrides, the latter having generally a grenter density. The density gradually and successively increases as the hydrate loses its water, until it attains its maximum in the anhydrides or oxides themselves. For example :-

\begin{tabular}{|c|c|c|c|}
\hline & & $\begin{array}{l}\text { Molecular } \\
\text { weight. }\end{array}$ & Density. \\
\hline $\int \mathrm{Mg}(\mathrm{OH})$ & Brucite & 58 & $2 \cdot 34$ \\
\hline$\{\mathrm{MgO} \ldots$ & Periclase.. & 40 & $3 \cdot 65$ \\
\hline $\int \mathrm{Zn}(\mathrm{OH})_{2}$ & Crystallized...... & 99 & $2 \cdot 677$ \\
\hline$Z_{n}$ & $\{$ Crystallized...... & 81 & 6.00 about \\
\hline (ail ........... & Amorphous ...... & 81 & $5 \cdot 60$ \\
\hline$\left\{\mathrm{Mn}_{2} \mathrm{O}_{3} \cdot \mathrm{H}_{2} \mathrm{O} \ldots\right.$ & Acerdese .......... & 176 & $4: 325$ \\
\hline $\mathrm{B}(\mathrm{OH})_{3}$. & $\begin{array}{l}\text { Braunite .......... } \\
\text { Crystallized..... }\end{array}$ & $\begin{array}{r}158 \\
62\end{array}$ & 1.48 \\
\hline $\mathrm{B}_{2} \mathrm{O}_{3} \ldots \ldots \ldots$ & Fused ........ & 70 & 1.83 \\
\hline $2 \mathrm{Fe}_{2} \mathrm{O}_{3} \cdot 3 \mathrm{H}_{2} \mathrm{O}$ & Limonite .... & 374 & $3 \cdot 6$ to 4.0 \\
\hline 2 & Göthite $\ldots$ & 178 & $4 \cdot 0$ to 4.4 \\
\hline $\mathrm{Fe}_{2} \mathrm{O}_{3}$ & $\begin{array}{l}\text { Oligiste .. } \\
\text { Calcined .. }\end{array}$ & $\begin{array}{l}160 \\
160\end{array}$ & $\begin{array}{l}5 \cdot 24 \text { to } 5 \cdot 28 \\
5 \cdot 04 \text { to } 5 \cdot 17\end{array}$ \\
\hline $\mathrm{Al}_{2} \mathrm{O}, 3 \mathrm{H}_{2} \mathrm{O}$ & Hydrargillite ... & 157 & $2 \cdot 35$ \\
\hline $\mathrm{Al}_{2} \mathrm{O}_{3} \cdot \mathrm{H}, \mathrm{O}$ & Diaspore .......... & 121 & $3 \cdot 45$ \\
\hline $\mathrm{Al}_{2} \mathrm{O}_{3} \quad \cdots$ & Corundum ....... & 103 & 4.00 \\
\hline
\end{tabular}

It should be noticed that a marked difference in density is observed in the case of substances which are known to be polymeric, thus :-

\begin{tabular}{|c|c|c|c|}
\hline & & $\begin{array}{c}\text { Mole- } \\
\text { cular } \\
\text { weight. }\end{array}$ & Density. \\
\hline $\mathrm{O}_{2} \mathrm{H}_{4} \mathrm{O}$ & 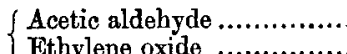 & 44 & 0.801 at $0^{\circ}$. \\
\hline$\left(\mathrm{C}_{0} \mathrm{H}_{3}\right.$ & Withylene oxide ......... & $\begin{array}{l}44 \\
88\end{array}$ & $\begin{array}{l}0.898 \% \\
1.048,\end{array}$ \\
\hline$\left(\mathbf{O}_{2} \mathbf{H}_{1} \mathrm{O}\right.$ & Paraldehyde ...................... & 132 & 0.998 at $15^{\circ}$ \\
\hline $\mathrm{C}_{5} \mathrm{H}_{8} \quad \ldots \ldots$ & Isopropylacetylene............ & 68 & 0.652 at $11^{\circ}$. \\
\hline$\left\{\mathrm{C}_{10} \mathrm{H}_{16}\right.$. & Terebenthene .................... & 136 & 0.8767 at $0^{\circ}$. \\
\hline $\mathrm{O}_{20} \mathbf{H}_{32}^{10}$. & Colophene ....................... & 272 & 0.94 at $9^{\circ}$ \\
\hline$\left(\mathrm{C}_{5} \mathrm{H}_{10} \cdots \cdots\right.$ & Amylene ............................ & 70 & 0.663 at $0^{\circ}$. \\
\hline $\mathrm{C}_{10} \mathrm{H}_{20} \cdots \cdots$ & Diamylene ............. & 140 & 0.777 \\
\hline & Triamylene ....... & 210 & 0.81 \\
\hline
\end{tabular}

Relations similar to those which are observed between the hydroxides and the oxides also exist between the latter and the chlorides. The densities of the oxides of the radicals $\mathrm{C}_{n} \mathrm{H}_{2 n}$ are notably less than those of the corresponding chlorides, and this difference is in some degree similar to that between the molecular weights of these compounds, thus :- 
Prof. Louis Henry on the Polymerization

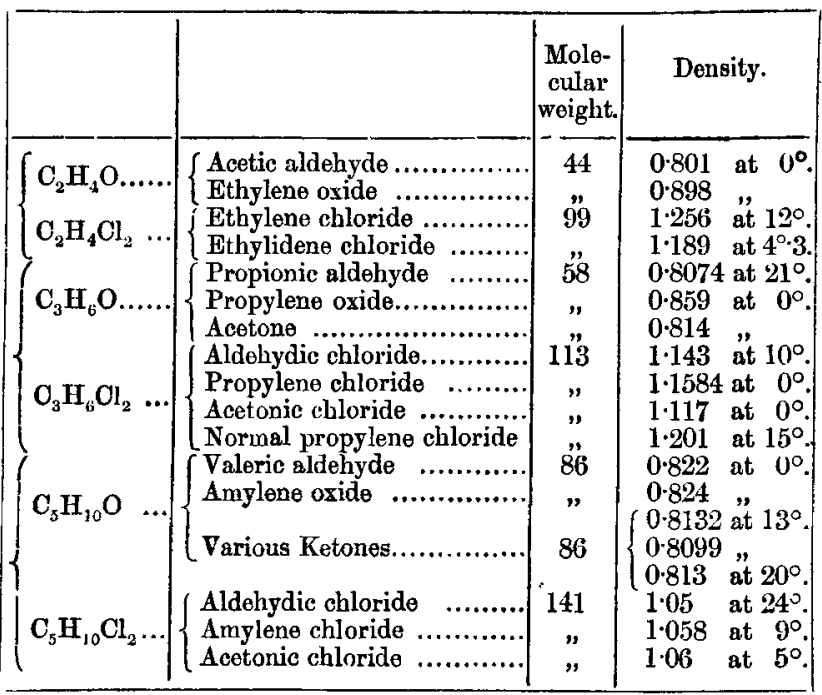

Now the difference between the density of the chlorides and oxides of the metals in general is exactly the inverse of the above, for the density of the oxides is notably greater than that of the apparently analogons chlorides, thus :-

\begin{tabular}{|c|c|c|c|}
\hline & & $\begin{array}{c}\text { Mole- } \\
\text { cular } \\
\text { weight. }\end{array}$ & Density. \\
\hline 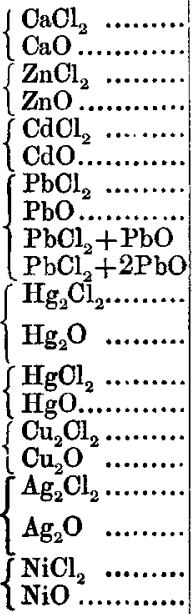 & $\begin{array}{l}\text { (Crystallized) } \ldots \\
\text { (Fused) ........... } \\
\text { Fused } \quad \ldots \ldots \ldots \ldots \ldots\end{array}$ & \begin{tabular}{|r|}
111 \\
56 \\
136 \\
81 \\
183 \\
128 \\
278 \\
223 \\
491 \\
724 \\
471 \\
416 \\
271 \\
216 \\
198 \\
143 \\
287 \\
232 \\
$129 \cdot 75$ \\
$74 \cdot 75$
\end{tabular} & 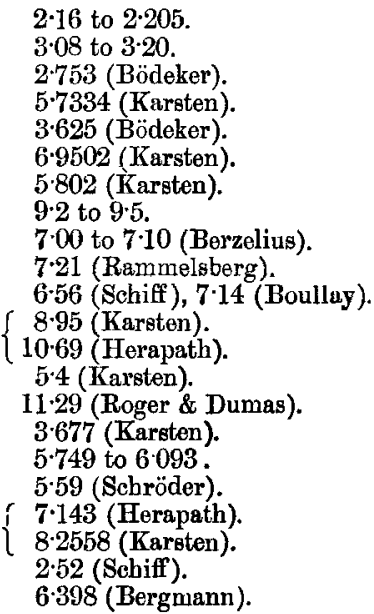 \\
\hline
\end{tabular}


A difference of the same kind exists between the oxides and the corresponding carbonates, thus :-

\begin{tabular}{|c|c|c|}
\hline $\begin{array}{l}\left\{\begin{array}{l}\mathrm{MgO} \\
\mathrm{MgCO}_{3}\end{array}\right. \\
\left\{\begin{array}{l}\mathrm{ZnO} \ldots \ldots \\
\mathrm{ZnCO}_{3} \ldots\end{array}\right. \\
\begin{array}{l}\mathrm{CaO} \ldots \ldots \\
\mathrm{CaCO}\end{array} \\
\left\{\begin{array}{l}\mathrm{SrO} \ldots \ldots \\
\mathrm{SrCO}_{3} \ldots\end{array}\right. \\
\left\{\begin{array}{l}\mathrm{PbO} \ldots \ldots \\
\mathrm{PbCO}_{3} \ldots\end{array}\right. \\
\left\{\begin{array}{l}\mathrm{BaO} \ldots \ldots \\
\mathrm{BaCO}_{3} \ldots\end{array}\right.\end{array}$ & 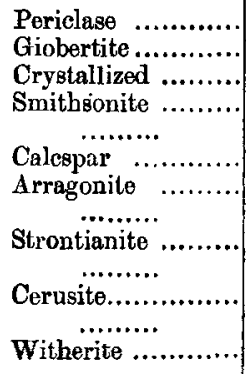 & $\begin{array}{c}3 \cdot 65 \\
2 \cdot 99 \text { to } 3 \cdot 15 \\
6 \cdot 00 \\
4 \cdot 3 \text { to } 4 \cdot 45 \\
3 \cdot 08 \text { to } 3 \cdot 2 \\
2 \cdot 7 \\
2 \cdot 9 \\
4 \cdot 61 \\
\mathbf{3} \cdot 6 \\
\mathbf{9} 2 \text { to } 9 \cdot 5 \\
\mathbf{6} \cdot \mathbf{5 7} \\
\mathbf{5} \cdot \mathbf{4} \\
4 \cdot 28\end{array}$ \\
\hline
\end{tabular}

The great difference observed between the density of certain oxides and that of their basic anhydrous salts is equally worthy of note, thus :-

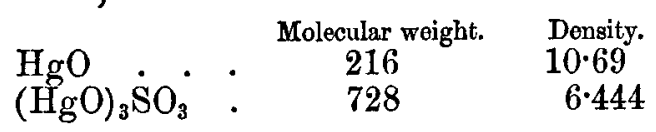

A study of the oxides, from both a physical and chemical point of view, leads, therefore, to the general conclusion, that for the most part the oxides cannot be compared with the chlorides; that the true oxides which are really comparable with the chlorides are unknown; and that we possess only polymers thereof $\left(\mathrm{RO}_{x}\right)_{n}$.

\section{Value of the Coefficient of Polymerization.}

What, now, is the true value of the coefficient $n$ of polymerization? What is the real molecular formula of these polymeric oxides? These questions are doubtless of great interest, but it should be stated at once that it is absolutely impossible to give an exact answer. I do not know of any fact which wonld allow us to assign an absolute value to the coefficient $n$ of polymerization, for we are in exactly the same position in respect to the metallic oxides as we are in the case of the solid polymeric ones of organic chemistry, e. $g$. methylene oxide, metaldehyde, \&c. So far as facts will permit of a conclusion, we may affirm that in most cases this number is very high, although different for different oxides. The molecular weight of most oxides should therefore be considerable. This conclusion results from a consideration of certain facts proviously referred to, and to which it will be necessary to return for a moment. 
Oxygen is an element endowed in reality, in spite of appearances to the contrary, with great power of volatilization. It forms oxides which are gaseous, or at least very volatile, with elements which are relatively but little volatile, as sulphur; or which are even entirely fixed, as carbon and osmium. To these normal oxides, which are regular at least in their physical properties, there correspond chlorides which are notably less volatile, as in the case of those of carbon:-

$$
\begin{aligned}
& \mathrm{CO}_{2} \text { gaseous, b.-p. }-78 . \\
& \mathrm{CCl}_{4} \text { liquid, b. } . \text { p. }+76 .
\end{aligned}
$$

That being so, it may be affirmed that many of the regular metallic oxides which correspond to the chlorides should be gaseous at the ordinary temperature, or at least very volatile. This should be especially true of $\mathrm{SiO}_{2}, \mathrm{Al}_{2} \mathrm{O}_{3}$, \&c.; for $\mathrm{SiCl}_{4}$ is a liquid boiling at $58^{\circ}$, and $\mathrm{Al}_{2} \mathrm{Cl}_{6}$ a solid volatile below $100^{\circ}$. In reality, however, these oxides, which $\mathrm{I}$ regard as polymers, $\left(\mathrm{SiO}_{2}\right)_{n}$ and $\left(\mathrm{Al}_{2} \mathrm{O}_{3}\right)_{n}$, are fixed solids. Organic chemistry furnishes examples of the relationships which exist in poly-

\begin{tabular}{|c|c|c|c|c|c|}
\hline \multirow[b]{2}{*}{ Ethylene oxic } & \multicolumn{3}{|c|}{ Molec. wt. } & \multirow{2}{*}{\multicolumn{2}{|c|}{ B.-p. Difference. }} \\
\hline & & & lio & & \\
\hline & $\left(U_{2}\right.$ & & & 102 & \\
\hline & & - $\quad 44$ & $\operatorname{liq}$ & 21 & 10 \\
\hline & & 132 & liquid & 124 & \\
\hline
\end{tabular}
mers between the volatility and molecular weight, thus :-

We thus see what is the difference in volatility between bodies of which the molecular weight in the state of gas is simple, double, or treble.

Now between a body which ought to be gaseous or very volatile, such as $\mathrm{SiO}_{2}$, and a fixed body, such as silica really is, there is a difference which cannot be compared to that which separates (as regards volatility) ethylene oxide and aldehyde from their polymers. If silica is, as $I$ believe, a polymer $\left(\mathrm{SiO}_{2}\right)_{n}$, then the value of $n$ should be considerable, and the molecular weight therefore very high. We come to the same conclusion if we consider the examples which are furnished by the relative densities of the chlorides and oxides of the radicals $\mathrm{C}_{n} \mathrm{H}_{2 n}$ and those of their polymers. As already remarked above, the density of the chlorides is higher than that of the corresponding oxides, whereas the densities of the polymers of the latter rise, approaching those of the chlorides, and even going beyond. The densities of the metallic oxides are often considerably greater than those of the chlorides. If we 
bear in mind the small difference which exists between the density of the oxides $\mathrm{C}_{n} \mathrm{H}_{2 n} \mathrm{O}$ and that of their polymers $\left(\mathrm{C}_{n} \mathrm{H}_{2 n} \mathrm{O}\right)_{2}$ or $\left(\mathrm{C}_{n} \mathrm{H}_{2 n} \mathrm{O}\right)_{3}$, we are led to conclude that the coefficient $n$ of polymerization of the metallic oxides must be very high, in order to raise the density of an oxide to nearly double that of the corresponding chloride, as is frequently the case.

Doubtless the molecular condensation is different with different metallic oxides. A priori we should expect it to be so. This is proved by the fact that the difference between the fusibility, volatility, density, \&c. of the oxides and the corresponding chlorides is very different in the several cases.

This condensation appears to attain its maximum in certain fixed and very infusible oxides, such as silica and alumina \&c., the corresponding chlorides being eminently volatile. This enormous condensation of their molecules may possibly be the cause of the greater resistance which they offer to the action of chemical agents, more especially to simple chemical agents such as $\mathrm{H}, \mathrm{C}, \mathrm{Cl}, \mathrm{S}$, \&c.

\section{Origin and Mechanism of the Polymerization of the Oxides.}

What is the origin, or, rather, what is the mechanism, of this molecular condensation which is so general in the oxides, and yet so absent in the chlorides? The diverse chemical nature of the two elements accounts for the different molecular behaviour of their compounds.

Chlorine is essentially a monovalent element, whilst oxygen is divalent. The result of this quality in oxygen is the possibility of its uniting by its two affinities with two polyvalent radicals.

From the atomic and molecular point of view, polymerization consists essentially in a simple change in which each atom of oxygen becomes united to two different atoms of the radical belonging to different molecules, and maintains them permanently together as a whole. The conversion of acetic aldehyde into its triple polymer, paraldehyde, is an interesting example of this atomic migration :-

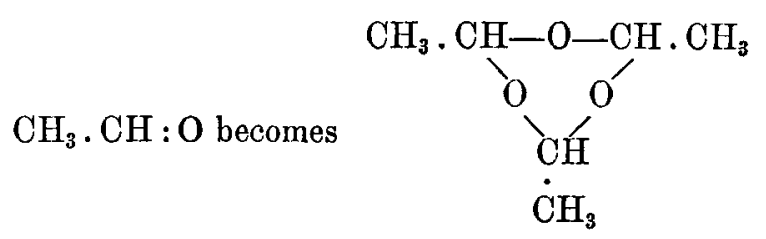

Similar facts occur, and in a similar manner, in the case of the metallic oxides, thus :- 

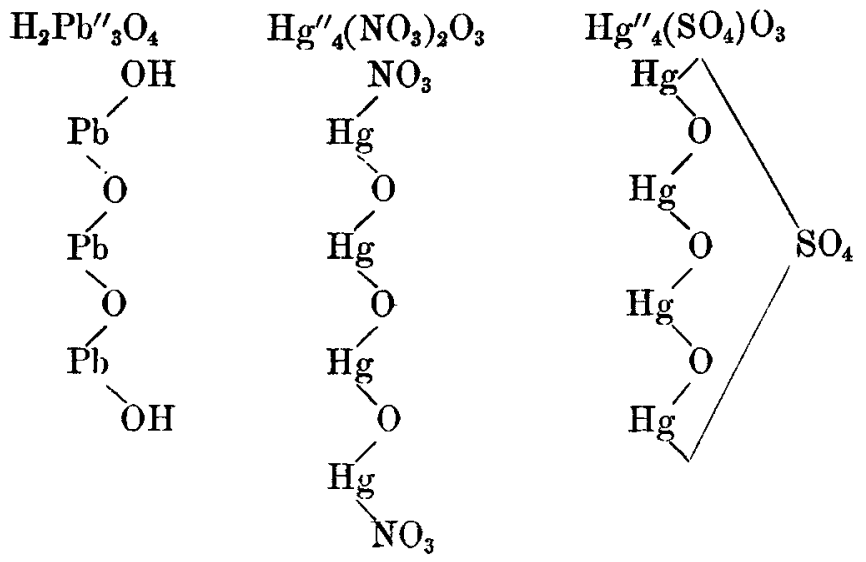

The corresponding polymeric oxides $(\mathrm{PbO})_{n}$ and $(\mathrm{HgO})_{n}$ being probably represented by analogous formulæ :-

$(\mathrm{PbO})_{n}$

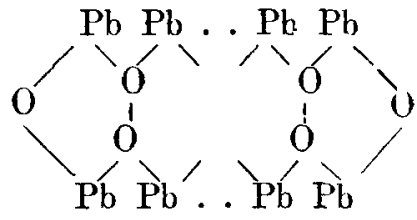

$(\mathrm{HgO})_{n}$

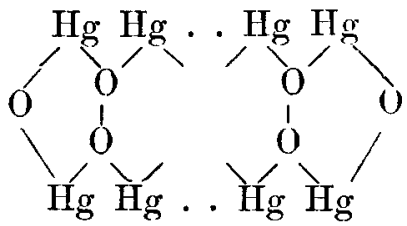

There is thus formed a kind of closed chain of polyvalent radicals alternating with $n$ atoms of oxygen. It is thus seen that the number of atoms of the radical $R$ accumulated in such a complex molecule may be considerable, and is theoretically illimitable. Similar groupings cannot occur in the case of the chlorides, on account of the nature of chlorine, which is a monovalent element, and consequently incapable of uniting directly with two other distinct atoms. All molecular condensation thus disappears, when in a polymeric oxide the oxygen is replaced by chlorine, as in the case of $\left(\mathrm{As}_{2} \mathrm{O}_{3}\right)_{2}$, which, under the action of chlorine, is converted into $\mathrm{AsCl}_{3}$. Also, as in the case of the polymers $\left(\mathrm{C}_{n} \mathrm{H}_{2 n} \mathrm{O}\right)_{x}$, more especially those of aldehydes, which are converted by $\mathrm{PCl}_{5}$ into the chlorides $\mathrm{C}_{n} \mathrm{H}_{2 n} \mathrm{Cl}_{2}$, identical with those furnished by the oxides $\left(\mathrm{C}_{n} \mathrm{H}_{2 n} \mathrm{O}\right)$ themselves.

Heat of Formation of the Oxides.

The combination of a body with itself, or the act of polymerization, is accompanied by the development of heat, as 
with every combination of heterogeneous bodies ; and this disengagement of heat may sometimes be considerable, as in the case of the internal combustion (spontaneous in the complete sense of the word), which certain metallic oxides undergo on heating (oxydes cuits of Chevreul).

The quantity of heat disengaged on the formation of an oxide $\mathrm{RO}_{x}$ in the direct way has a double origin, viz. the heat of combination of the elements and the heat of polymerization; so that the direct formation of a chloride is not at all comparable with that of an oxide. A comparison, therefore, of the phenomena of combination, from the physical point of view, show's that the heat evolved is an absolute measure of the difference of the affinities between the elements of the compound. That being so, we should conclude that the difference between the affinity of oxygen and chlorine for the metals is in reality greater than the thermal phenomena, as determined directly, would lead us to assume.

\section{Action of Heat on the Oxides-their Classification.}

The oxides may be divided into various groups, according to the changes which they undergo on heating.

A. Normal or Regular Uxides, which correspond molecularly to the chlorides. These oxides are few in number, e. $g$. $\mathrm{SO}_{2}, \mathrm{CO}_{2}, \mathrm{NO}, \mathrm{N}_{2} \mathrm{O}, \mathrm{CO}$, \&c.

B. Polymerized Oxides, the molecules of which are made up of $n$ molecules of the normal oxide united together. This group includes most oxides, and may be divided into several classes according to the action of heat thereon; viz. :-

(1) Volatile oxides, which are totally depolymerized on heating, and in the state of vapour are converted into the normal oxide. The number of these oxides is limited, and they are of two kinds :-

(a) Oxides which are completely depolymerized on volatilization, yielding a vapour of normal density, e. g. $\mathrm{SO}_{3}$, $\mathrm{OsO}_{4}$, and probably $\mathrm{RuO}_{4}$; also varions organic oxides, such as methylene oxide $\left(\mathrm{CH}_{2} \mathrm{O}\right)_{n}$, metaldehyde $\left(\mathrm{CH}_{3} . \mathrm{CHO}\right)_{n}$, and aldehydes and acetones in general. On condensation the original polymeric oxides are re-formed.

(b) Oxides which are depolymerized very imperfectly at the moment of volatilization, and only completed progressively as the temperature rises. The vapour-density of these bodies, therefore, gradually diminishes with increase in temperature up to a certain point, beyond which it becomes constant, and corresponds to that of the normal oxide, e. g. $\mathrm{N}_{2} \mathrm{O}_{4}$, fatty acids, and paral- 
dehyde. The vapour-density of the last corresponds to $\left(\mathrm{C}_{2} \mathrm{H}_{4} \mathrm{O}\right)_{3}$ at low temperatures, and at higher temperatures to $\left(\mathrm{C}_{2} \mathrm{H}_{4} \mathrm{O}\right)$, $i$. e. the normal aldehyde.

(2) Volatile oxides, which are only depolymerized imperfectly, at least at the temperatures to which they have been subjected; e. g. $\left(\mathrm{As}_{2} \mathrm{O}_{3}\right)_{n}$, the gaseous molecule of which is $\left(\mathrm{As}_{2} \mathrm{O}_{3}\right)_{2}^{*}$.

Lactide, or the dioxide of the radical $\mathrm{C}_{3} \mathrm{H}_{4}$ iv $\left(\right.$ or $\mathrm{CH}_{3}$. $\mathrm{CH}$. $\left.\mathrm{C} \equiv\right)$ ),

is perfectly analogous to arsenious oxide, its molecule in the state of vapour corresponding to $\left(\mathrm{C}_{3} \mathrm{H}_{4} \mathrm{O}_{2}\right)_{2}$. Ethylene dioxide $\left(\mathrm{C}_{2} \mathrm{H}_{4} \mathrm{O}\right)_{n}$ probably belongs to this class, as in the state of vapour its molecule $=\left(\mathrm{C}_{2} \mathrm{H}_{4} \mathrm{O}\right)_{2}$.

(3) Oxides which are not capable of depolymerization. Most inorganic oxides belong to this group; also the oxides of certain organic radicals.

They are of two kinds :-

(a) Oxides which are absolutely indepolymerizable and fixed, as in the case of many metallic oxides which are not decomposed by heat; e. g. $\mathrm{SiO}_{2}, \mathrm{~B}_{2} \mathrm{O}_{3}, \mathrm{SnO}_{2}, \mathrm{ZnO}$, $\mathrm{MgO}, \mathrm{Fe}_{2} \mathrm{O}_{3}, \mathrm{Cr}_{2} \mathrm{O}_{3}, \mathrm{Al}_{2} \mathrm{O}_{3}, \mathrm{PbO}, \mathrm{CuO}, \mathrm{Cu}_{2} \mathrm{O}$, \&c.

(b) Oxides which are indepolymerizable, because on heating they are decomposed either into their elements or into new compounds, as in the case of several metallic oxides ; e. g. $\mathrm{HgO}, \mathrm{Ag}_{2} \mathrm{O}, \mathrm{Hg}_{2} \mathrm{O}, \mathrm{CrO}_{3}, \mathrm{MnO}_{2}$, \&c., and also of certain organic oxides, as glycollide $\left(\mathrm{C}_{2} \mathrm{H}_{2} \mathrm{O}_{2}\right)_{n}$, which carbonizes on heating.

The above classification is conveniently represented in the folluwing table ( $p .113)$.

It follows from all these facts and considerations that there are large and important lacunæ in the series of oxygenated compounds of Mineral Chemistry. Shall we ever be able to obtain the whole series of normal oxides, of which we have at present so few examples? I know not. But to produce them we should doubtless have to work under conditions totally different from those which are usually employed. Our actual methods of preparation are precisely those under which these unknown bodies polymerize, and thus escape us. If it be rash to hope to obtain these bodies in the near future, it would be still more so to say that their discovery was impossible. This word is profoundly repugnant to our tendencies and scientific habits. When we measure the progress of science since the commencement of the century in a domain so vast as Chemistry, there are many reasons for not being discouraged.

* Arsenious oxide volatilizes, as is well known, at about $200^{\circ}$ without melting. This temperature is not the boiling-point properly so called, but is really the temperature of depolymerization of the molecule $\left(A s_{2} \mathrm{O}_{3}\right)_{n}$ into $\left(\mathrm{As}_{2} \mathrm{O}_{3}\right)_{2}$. 
of the Metallic Oxides.

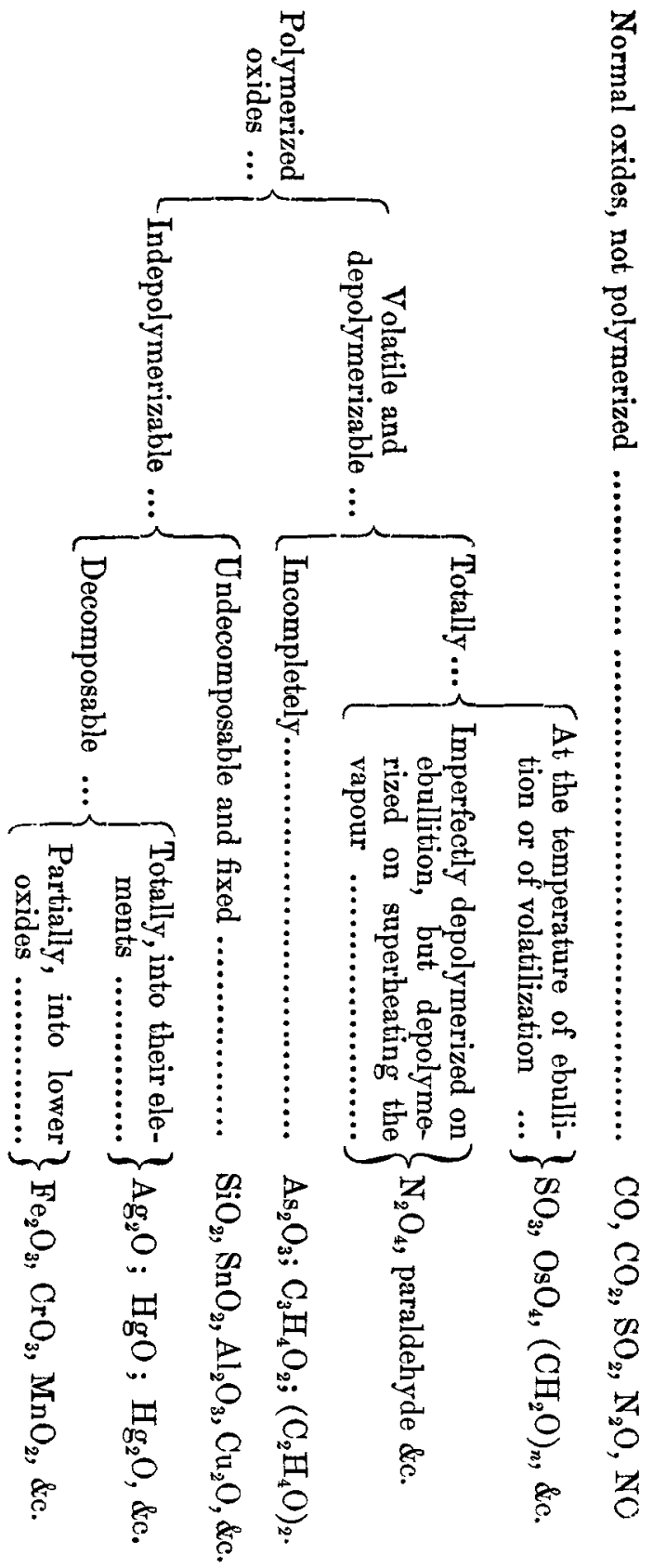

Phil. Mag. S. 5. Vol. 20. No. 123. August 1885. I 


\section{APPENDIX. \\ Dehydration and Condensation of the Hydroxides by Heat.}

It has been already stated that the hydroxides, under the action of a gradually increasing temperature, undergo a progressive dehydration, whilst at the same time their molecules become more and more condensed by the accumulation of the residual oxyhydroxides of the radical of the primitive compound. What is the cause of this general fact? This phenomenon is analogous, both in appearance and result, to that of direct etherification, i.e. to the action of an acid on an alcohol. In fact, etherification is an example of the production of an anhydrous oxide from its hydroxide. The most simple case is that in which we can follow step by step the work of dehydration, as with ordinary lactic acid.

Lactic acid, $\mathrm{C}_{3} \mathrm{H}_{6} \mathrm{O}_{3}$, is the dihydroxide of the radical lactyl, $\mathrm{C}_{3} \mathrm{H}_{4} \mathrm{O}$, which we may represent by La. On heating, lactic acid gives successively two anhydrides, the so-called lactic anhydride,

$$
2 \mathrm{C}_{3} \mathrm{H}_{6} \mathrm{O}_{3}-\mathrm{H}_{2} \mathrm{O}=\mathrm{HO} \text {. La . O . La . OH, }
$$

and lactide,

$$
2 \mathrm{C}_{3} \mathrm{H}_{6} \mathrm{O}_{3}-2 \mathrm{H}_{2} \mathrm{O}=\mathrm{La} \text {. O . La. O. }
$$

The delydration thus takes place in two steps, and requires at least two molecules of acid - a fact which is easily understood from the usual formula of lactic acid,

$$
\mathrm{CH}_{3} \text {. } \mathrm{CH}(\mathrm{OH}) \text {. } \mathrm{COOH} \text {. }
$$

The two hydroxyl groups are not equivalent; the one is acid and the other alcoholic; so that the action of heat on lactic acid is really the action of an acid on an alcohol, which mutually and successively undergo etherification, giving the so-called lactic anhydride, which is at the same time an acid, an alcohol, and an ether,

$$
\underset{\substack{\mathrm{CH}_{3} \\ \mathrm{CH}_{3}}}{\mathrm{CH}(\mathrm{OH})} \cdot \mathrm{CO} \cdot \mathrm{OH}, \mathrm{COOH},
$$

and which furnishes lactide,

$$
\mathrm{CH}_{3} \text {. } \mathrm{CH} \text {. } \mathrm{CO} .0 . \stackrel{\mathrm{CH}_{3}}{\mathrm{CH}} \text {. CO. O, }
$$

which is only but doubly an ether. If the radical lactyl were known only en bloc, the reason of this difference in the nature of these hydroxyls would totally escape us. 
The molecule of lactide, which in the state of vapour is $\left(\mathrm{C}_{3} \mathrm{H}_{4} \mathrm{O}_{2}\right)_{2}$, ought in its natural state to be still more complex. The boiling-point of this substance is really the temperature at which the grouping $\left(\mathrm{C}_{3} \mathrm{H}_{4} \mathrm{O}_{2}\right)_{2 n}$ becomes $\left(\mathrm{C}_{3} \mathrm{H}_{4} \mathrm{O}_{2}\right)_{2}$. This is the logical conclusion from the molecular constitution of carboxylated acids. The molecule of acetic acid must be at least

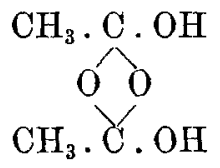

The formula $\mathrm{CH}_{3} . \mathrm{COOH}$, commonly attributed to this acid, only represents the product of the simplification of its molecule under the action of a high temperature. That being so, the molecule of lactic acid should be at least<smiles>CC(O)C(O)OC(O)(O)C(C)O</smiles>

In the formation of dilactic acid and of lactide, two of such molecules act on one another, and consequently the molecule of lactide ought to be at least $\left[\left(\mathrm{C}_{3} \mathrm{H}_{4} \mathrm{O}_{2}\right)_{2}\right]_{2}$, i. e. the double of its molecule in the state of vapour. However that may be, the hydroxides of the polyvalent radicals of mineral chemistry are assimilable to the above organic hydroxides; and we may therefore reasonably conclude that the hydroxyls which they contain are of different value. This question may be answered affirmatively and with certainty in some cases, notably that of phosphoric acid. Thomsen, Berthelot, and Longuinine have shown what is the real nature of this compound.

Orthophosphoric acid, $\mathrm{PO}(\mathrm{OH})_{3}$, is a tribasic acid, but of quite a different kind from citric acid, in so far as in the latter the three hydroxyls are perfectly equivalent, as shown by the identity of their heats of neutralization. Citric acid, as shown by its formula, is equivalent to three molecules of carbonic acid rolled into one.<smiles>O=C(O)CC(O)(CC(=O)O)C(=O)O</smiles> 
Phosphoric acid, on the contrary, is equivalent to three different acids, the heats of neutralization of the three basicities of the acid by the same metal being unequal.

$$
\begin{aligned}
\mathrm{H}_{3} \mathrm{PO}_{4}+\mathrm{NaHO} & =14 \cdot 68 \text { cals. } \\
+2 \mathrm{NaHO} & =26.33 \quad " \\
+3 \mathrm{NaHO} & =33.59 \quad "
\end{aligned}
$$

The substitution of hydrogen by sodium thus causes successively the evolution of $14 \cdot 68,11 \cdot 65$, and $7 \cdot 26$ cals. As regards two of its hydroxyls, orthophosphoric acid is strongly acid, though unequally, the one having an acidity similar to that of hydrochloric or nitric acid, and the other to carbonic acid; whilst the third hydroxyl is more like that of an alcohol or phenol.

The action of heat on phosphoric acid is really the action of heat on an acid-alcohol, and ought therefore to exhibit phenomena similar to those observed in the case of lactic acid. These phenomena ought even to be more complicated, because for one molecule of $\mathrm{PO}(\mathrm{OH})_{3}$ acting as an alcohol there is another molecule acting as an acid, and can function by one or other of its hydroxyls, which are not only acid, but unequally acid.

The formation of pyrophosphoric acid seems to be perfectly analogous to that of phosphoglyceric acid, thus :-

$$
(\mathrm{HO})_{2} \mathrm{PO} \text {. O . } \mathrm{PO}(\mathrm{OH})_{2} \quad(\mathrm{HO})_{2} \cdot \mathrm{C}_{3} \mathrm{H}_{5} \cdot \mathrm{O} . \mathrm{PO}(\mathrm{OH})_{2} \text {. }
$$

Two isomers, however, appear possible. Besides the three hydroxyls of phosphorio acid having a different chemical value, it follows that the products of the phosphoric etherification, from the partial dehydration of $\mathrm{H}_{3} \mathrm{PO}_{4}$, ought to be very numerous and complicated. Our present knowledge of the action of heat on this acid is therefore very superficial.

Can we refer the condensation of the metallic polyhydroxyls under the action of heat to the same cause-i.e. to a difference in the nature and value of the several hydroxyls? It seems natural and logical to do so, but it is difficult to find sufficient authority.

Phosphoryl being a multiple radical, formed of heterogeneous atoms, one can rigorously account for the fact that the three hydroxyls, which are grouped around it, are unequally placed as regards these elements, and can therefore have different values. But to conclude that the different hydroxyls attached to the same polyvalent atom, such as $\mathrm{Si}$, Sn, \&c., have not the same value, it would be necessary to assume that the polyvalent atoms are not identical at all 
points, or at least that the various units of chemical action are not equivalent, and are therefore of unequal energy. Here we introduce one of the higher problems of chemical metaphysics. I abstain, however, from dealing with it at present.

If the condensation which certain hydroxides undergo on heating is explicable in certain cases, there are others much more numerous, which still remain without plausible explanation, and notably is this the case with the hydroxides of the elements.

\section{On the Oxide of Methylene, $\mathrm{CH}_{2}: \mathrm{O}$.}

There is no compound more interesting than this, from the point of view of the polymerization of the metallic oxides. There is a perfect parallel between the reactions by which it may be obtained from its ethers and those by which certain oxides are prepared from their salts. Just as the arsenious ethers under the action of water give arsenious anhydride, so do the methylenic ethers, when treated with water, give methylene oxide, $i$. e. its solid polymer.

These reactions may also be compared with those which give certain metallic oxides, as $\mathrm{Sb}_{2} \mathrm{O}_{3}, \mathrm{Bi}_{2} \mathrm{O}_{3}, \mathrm{H} . g \mathrm{O}$, \&c., by the decomposition of their salts with an excess of water, or by weak alkaline leys. Methylene $\left(\mathrm{CH}_{2}\right)$ acts in all respects like a metal, and its oxide is strictly comparable to a metallic oxide, with this difference, that when heated it is completely depolymerized on volatilization, whereas certain oxides, as $\left(\mathrm{As}_{2} \mathrm{O}_{3}\right)_{n}$, are only imperfectly depolymerized, whilst others, such as $\mathrm{HgO}, \mathrm{Bi}_{2} \mathrm{O}_{3}$, \&c., are fixed.

In a special paper $I$ intend to return to the oxides and chlorides of the dicarbon radicals $\mathrm{C}_{2}{ }^{\text {vi }}, \mathrm{C}_{2} \mathrm{H}_{2}{ }^{\text {iv }}, \mathrm{C}_{2} \mathrm{H}_{4}{ }^{i i}$.

XIV. On the Thermoelectric Position of Carbon. By John Buchanan*.

[Plate VIII.]

$\mathrm{T} N$ the very interesting paper read by Dr. J. A. Fleming 1 before this Society on March 14, 1885, whilst discussing the question of the life of incandescent lamps, the author remarks that quite a large proportion of the carbon filaments are found to break at the negative end, that is, near the point where the current passes from carbon to platinum. It seemed to me not improbable that the negative end of the carbon might be subjected to a heating action due to the operation

* Communicated by the Physical Society : read June 27, 1885. 